\title{
ANTICIPATING WiLl CONTESTS AND How To AvoID THEM
}

\author{
GERRY W. BEYER
}

\author{
Governor Preston E. Smith Regents Professor of Law \\ Texas Tech University School of Law \\ 1802 Hartford St. \\ Lubbock, TX 79409-0004 \\ (806) 742-3990 \\ gwb@ProfessorBeyer.com \\ http://www.ProfessorBeyer.com \\ http://www.BeyerBlog.com
}

\section{ESTATE ADMINISTRATION SEMINAR}

Texas Bankers Association

San Antonio, Texas

September 30, 2011 


\section{TABLE OF CONTENTS}

I. THE FLAGS OF CAUTION — REASONS TO ANTICIPATE A WILL CONTEST .................... 1

A. Disinheritance of Close Family Members in Favor of Distant Relative, Friend, or Charity.............1

B. Unequal Treatment of Children ........................................................................................................2

C. Sudden or Significant Change in Disposition Plan..................................................................................2

D. Imposition of Excessive Restrictions on Bequests ..........................................................................................2

E. Elderly or Disabled Testator .............................................................................................................2

F. Unusual Behavior of Testator ........................................................................................................................2

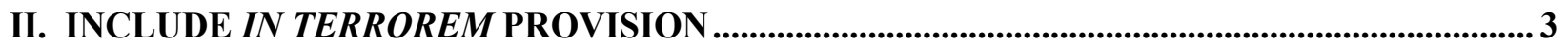

A. Validity and Enforceability ..........................................................................................................................

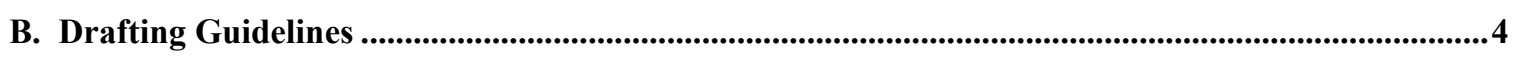

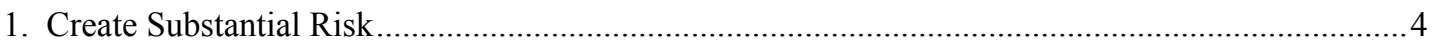

2. Describe Triggering Conduct …………………..................................................................

3. Indicate Beneficiary of Forfeited Property …………..............................................................

C. Sample Provisions ................................................................................................................................................5

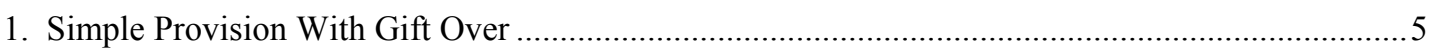

2. Simple Provision With Nominal Gift to Contestant ......................................................................

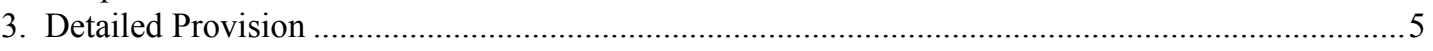

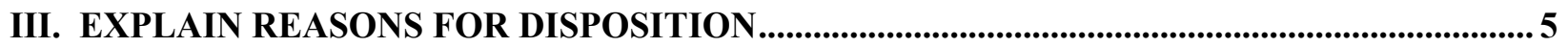

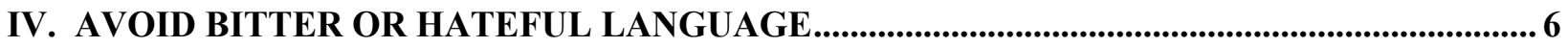

A. Encourages Will Contests ................................................................................................................6

B. Potential for Testamentary Libel ...........................................................................................................6

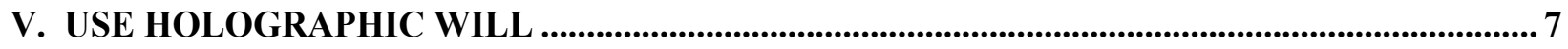

VI. ENHANCE TRADITIONAL WILL EXECUTION CEREMONY .............................................. 7

A. Prior to the Ceremony .............................................................................................................................

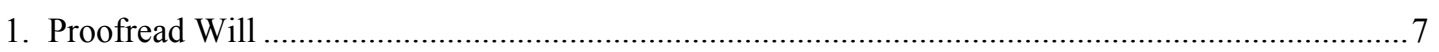

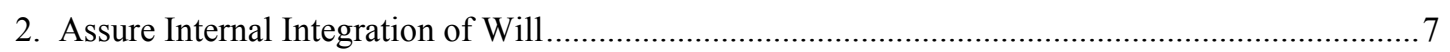

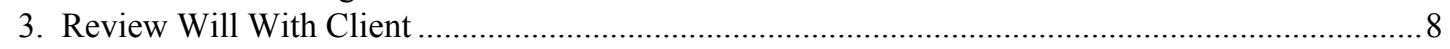

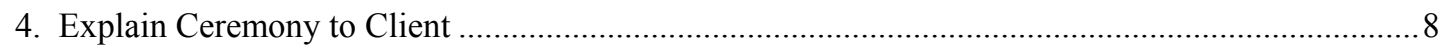

B. The Ceremony ...............................................................................................................................................

1. Select Appropriate Location ............................................................................................... 8

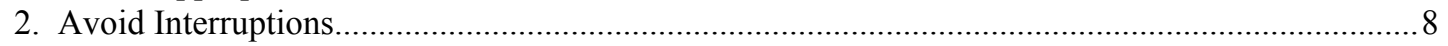

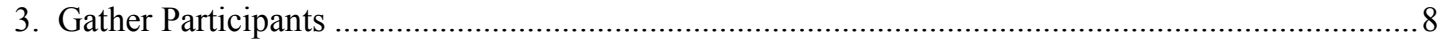

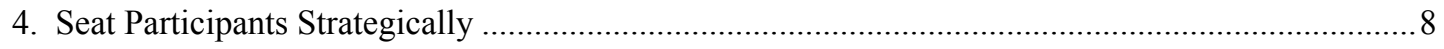

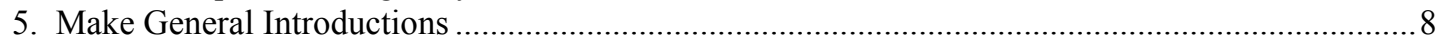

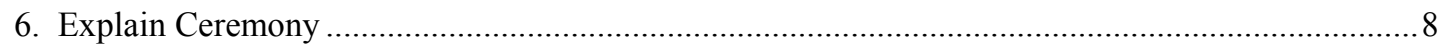

7. Establish Testamentary Capacity ......................................................................................

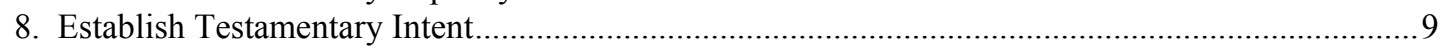




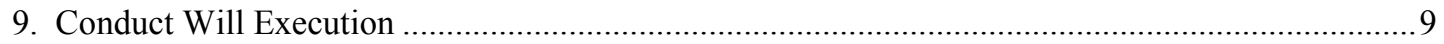

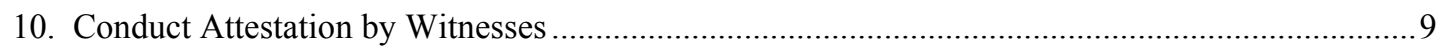

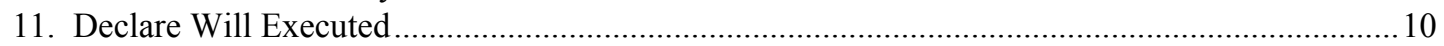

12. Complete Self-Proving Affidavit...................................................................................... 10

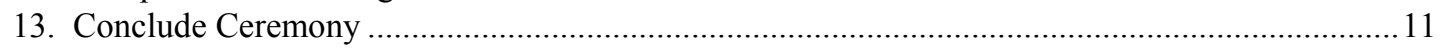

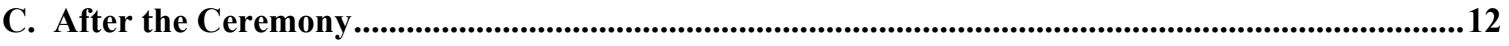

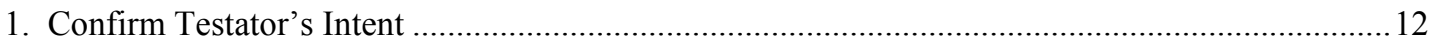

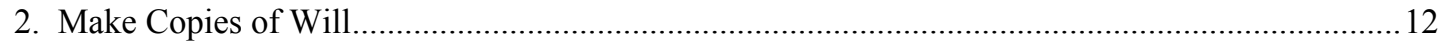

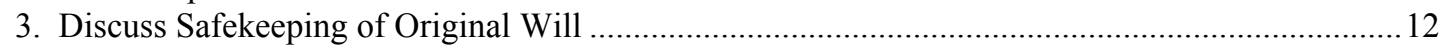

4. Destroy or Preserve Prior Will ..................................................................................... 12

5. Provide Testator With Post-Will Instructions .............................................................. 12

VII. MEMORIALIZE WILL EXECUTION CEREMONY ON VIDEO .................................13

A. Uses of Will Execution Video-recording................................................................................13

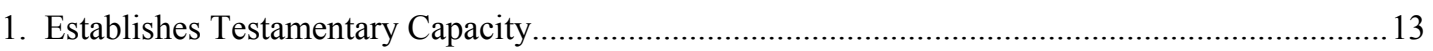

2. Shows Due Execution of Will ........................................................................................ 14

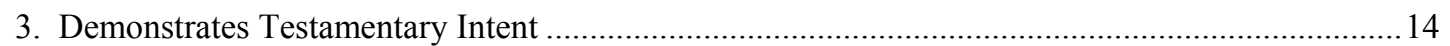

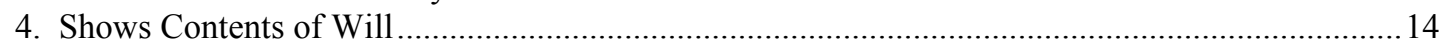

5. Establishes Lack of Undue Influence or Fraud....................................................................... 14

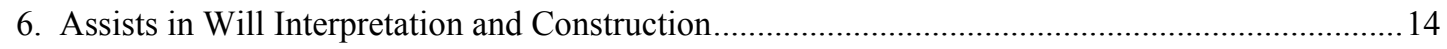

B. Admissibility of Will Execution Video-recording ..........................................................................14

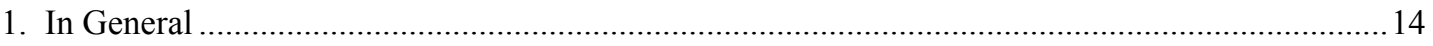

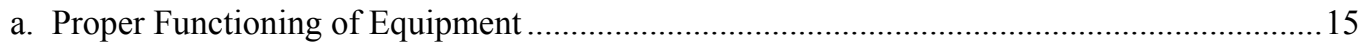

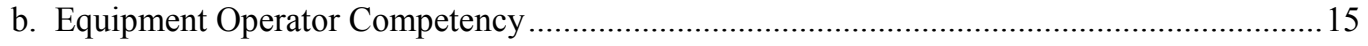

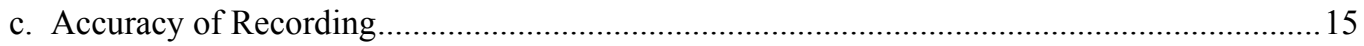

d. Proper Preservation of Recording ............................................................................... 15

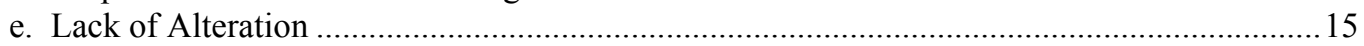

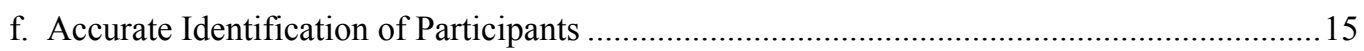

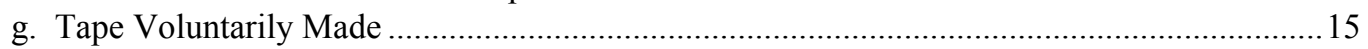

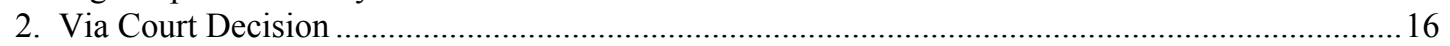

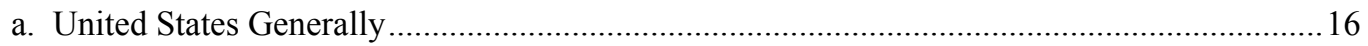

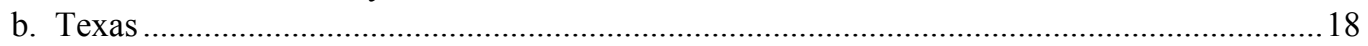

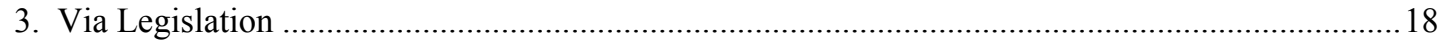

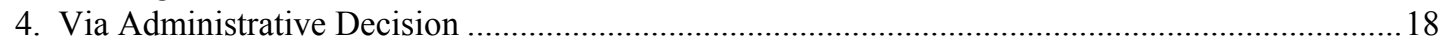

C. Advantages Over Other Types of Evidence ..................................................................................19

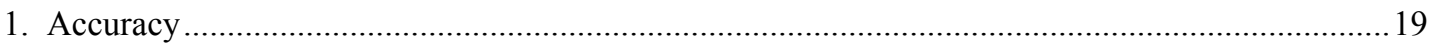

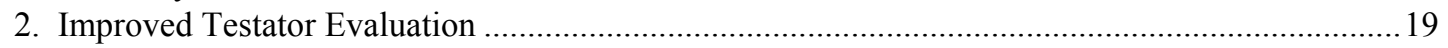

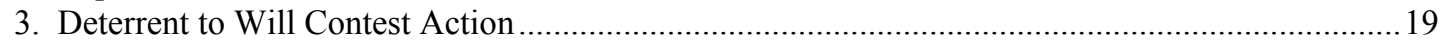

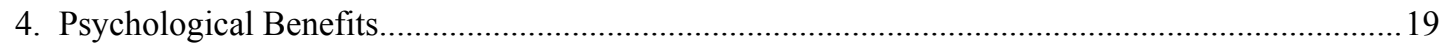

D. Potential Problems ............................................................................................................................19

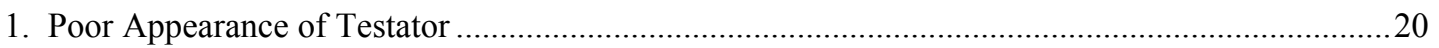

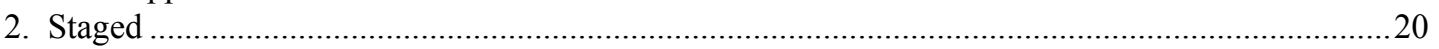

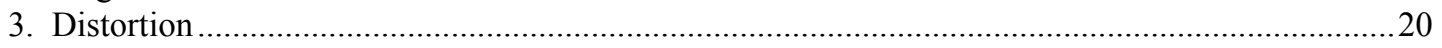

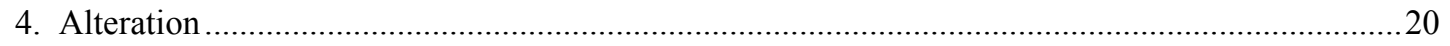

E. Procedure/Format for Videotaping Will Execution Ceremony........................................................21

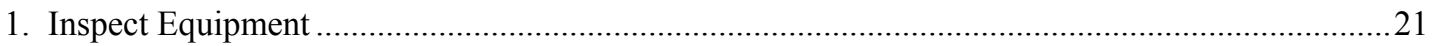

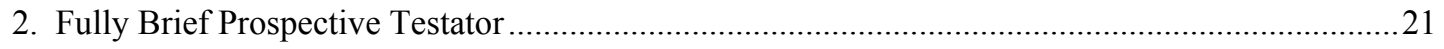

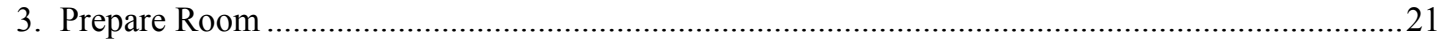

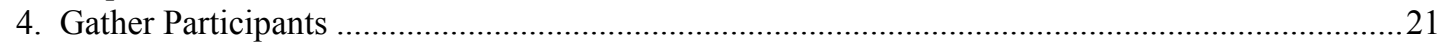

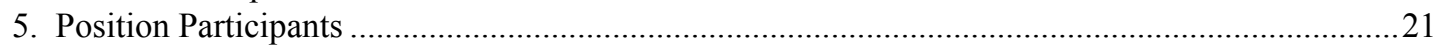

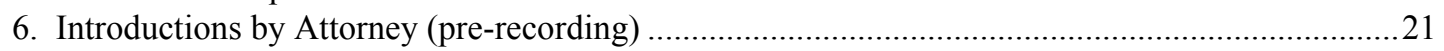


7. Begin Recording; Introduce Setting and Participants ..............................................................2 21

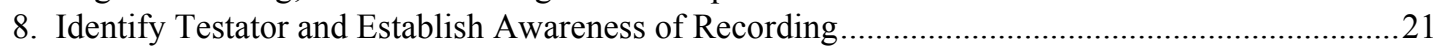

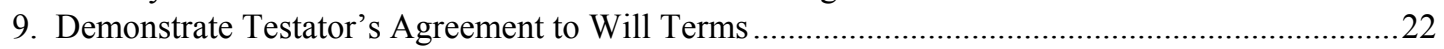

10. Establish Testator Understands Natural Objects of Bounty ......................................................22

11. Establish Testator Understands Nature and Extent of Property .................................................22

12. Establish Testator Understands Disposition of Property Made by Will ......................................22

13. Establish Lack of Undue Influence....................................................................................22

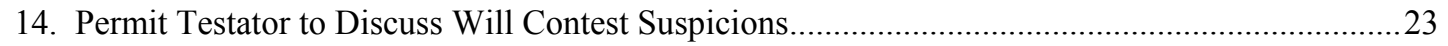

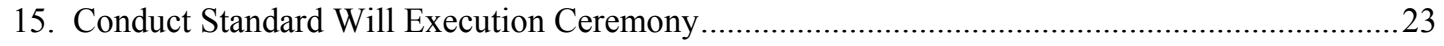

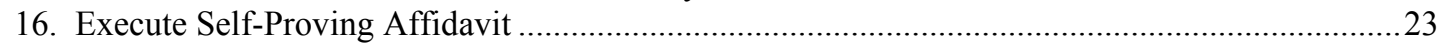

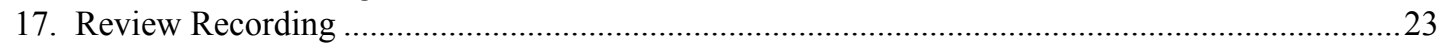

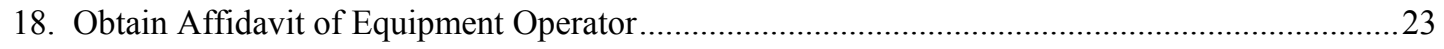

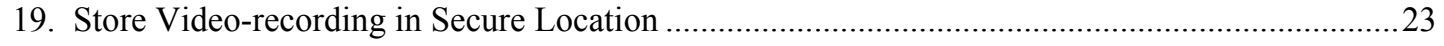

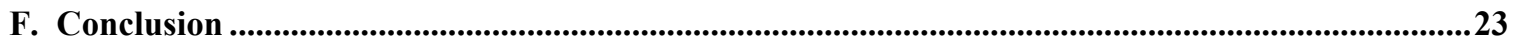

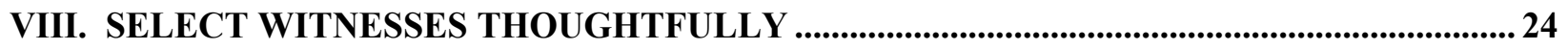

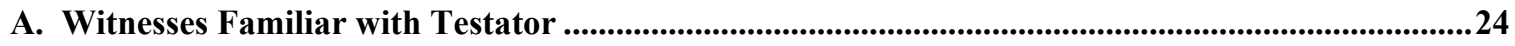

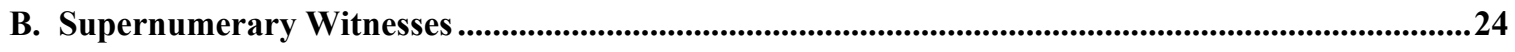

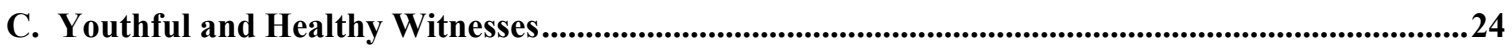

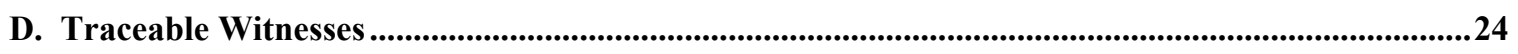

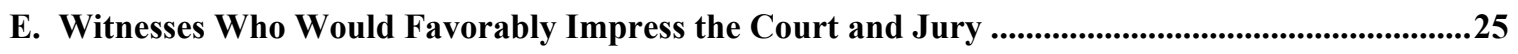

IX. OBTAIN AFFIDAVITS OF INDIVIDUALS FAMILIAR WITH TESTATOR ........................25

X. DOCUMENT TRANSACTIONS WITH TESTATOR VERIFYING INTENT .......................... 25

XI. OBTAIN OTHER EVIDENCE TO DOCUMENT TESTATOR'S ACTIONS ............................ 25

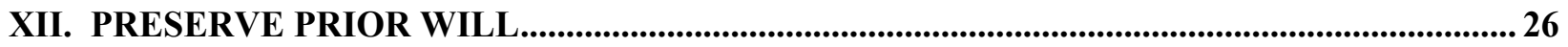

XIII. REEXECUTE SAME WILL ON REGULAR BASIS ........................................................... 26

XIV. SUGGEST THAT TESTATOR CONSIDER MAKING A MORE TRADITIONAL

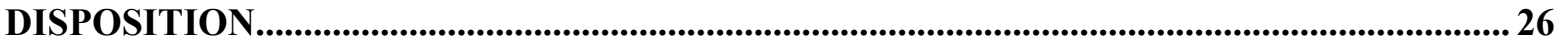

XV. MAKE SIGNIFICANT INTER VIVOS GIFT TO DISINHERITED HEIR APPARENT AT

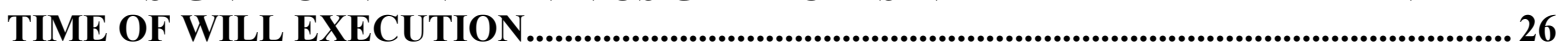

XVI. CONTRACT NOT TO CONTEST ....................................................................................................... 27

XVII. RECOMMEND USE OF ALTERNATIVE ESTATE PLANNING TECHNIQUES ............. 27

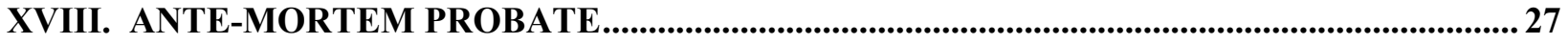

A. Significant Problems With Post-Mortem Probate Under Texas Law ..................................................28

1. Mere Technical Errors May Invalidate Otherwise Valid Will....................................................28

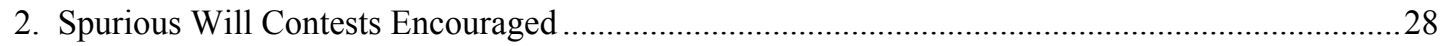

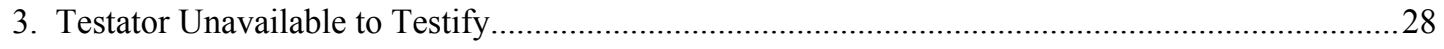

B. Development of Ante-Mortem Probate ..............................................................................29

1. The Michigan Attempt at Ante-Mortem Probate .........................................................................29

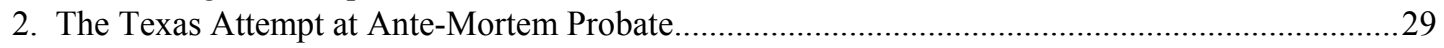


C. Current Status of Ante-Mortem Probate.................................................................................................30

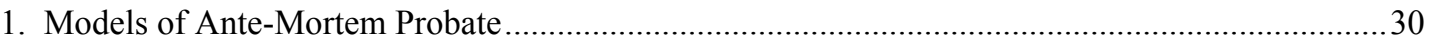

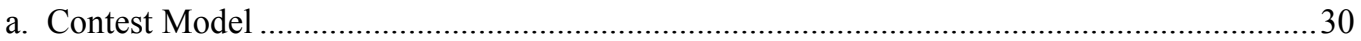

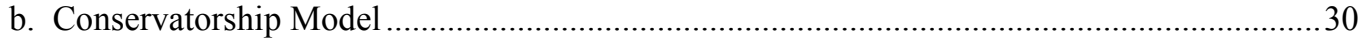

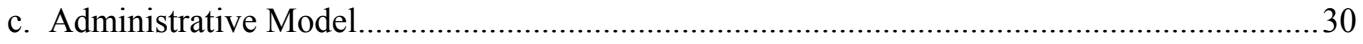

2. Jurisdictions Which Currently Have Ante-Mortem Probate ........................................................... 31

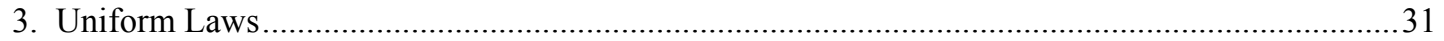

D. The Future of Ante-Mortem Probate ........................................................................................................31

XIX. TORTIOUS INTERFERENCE WITH INHERITANCE RIGHTS ............................................32 


\section{ANTICIPATING Will CONTESTS AND}

\section{How To AvoID THEM}

\section{THE FLAGS OF CAUTION - REASONS TO ANTICIPATE A WILL CONTEST}

An estate planner must always be on guard when drafting instruments which may supply incentive for someone to contest a will. Anytime an individual would take more through intestacy or under a prior will, the potential for a will contest exists, especially if the estate is large. Although will contests are relatively rare, the prudent attorney must recognize situations which are likely to inspire a will contest and take steps during the drafting stage to reduce the probability of a will contest action and the chances of its success. ${ }^{1}$

\section{A. Disinheritance of Close Family Members in Favor of Distant Relative, Friend, or Charity}

A will leaving nothing or only nominal gifts to close family members, such as a spouse of many years or children, is ripe for a contest action, especially if the beneficiaries are distant relatives, social friends, or charities. Juries are prone in close cases to invalidate a will which disinherits the surviving spouse and children, although "[i]t is not for courts, juries, relatives, or friends to say how property should be passed by will, or to rewrite a will for a testator because they do

1 See Jeffrey P. Rosenfeld, To Heir is Human, ProB. \& Prop., July/Aug. 1990, at 21, 25 (3-4\% of probated wills reach the trial stage of a will contest); Jeffrey A. Schoenblum, Will Contests An Empirical Study, 22 ReAl Prop. Prob. \& TR. J. 607 (1987) (extensive discussion of study done on will contests over a nine year period in Nashville, Tennessee). not believe he made a wise or fair distribution of his property." 2

Will contests based on property passing outside of the traditional family are likely to increase because of various societal changes. Many older individuals have significant involvement with people outside of the family in retirement communities and senior citizen organizations. The lifestyles of younger people include more divorces, childless marriages, cohabitation, and same-sex relationships. As a result, estate plans of these individuals are more likely to include gifts to non-family members and thus increase the likelihood of contests. One insightful commentator has noted:

Inheritance has traditionally been an occasion when families reconfirm the importance of kinship ties. The scant evidence from research on will contests shows more than property is at stake when families go to court. Usually there is concern that a traditional aspect of the family - a role, relationship, or the balance of power - has been violated by the terms of the trust or estate plan. Bequests outside the family - to friends, lovers, step-heirs, and so forth - may never become socially acceptable, even if they are increasingly common. These unconventional estate plans mean that family members will be more prone to litigate instead of accepting a decedent's estate plan .... [M]ost

2 Stephen v. Coleman, 533 S.W.2d 444, 445 (Tex. Civ. App.-Fort Worth 1976, writ ref'd n.r.e.) (quoting Farmer v. Dodson, 326 S.W.2d 57, 61 (Tex. Civ. App.-Dallas 1959, no writ)). 
families are unable - and unwilling to inherit less so that friends, organizations or lovers can inherit more. $^{3}$

\section{B. Unequal Treatment of Children}

A will which treats children unequally, especially if the children receiving disproportionately large amounts have no special needs, is likely to encourage spurned siblings to contest the will. The contestant's appeal to the inherent fairness of all children sharing equally may sway a wavering jury. ${ }^{4}$

\section{Sudden or Significant Change in Disposition Plan}

When a testator ${ }^{5}$ makes a sudden or significant change to the will's dispositive scheme, the beneficiaries of the old will who lose under the new will may be motivated to contest the new will. These beneficiaries will strive to show that the testator lacked capacity to change the will or that the testator was unduly influenced to make the alterations.

\section{Imposition of Excessive Restrictions on Bequests}

A testator may impose restrictions on gifts to heirs. For example, the will may create a testamentary trust for the children with

3 Jeffrey P. Rosenfeld, To Heir is Human, PROB. \& PROP., July/Aug. 1990, at 21, 25.

4 Cf. Birk v. First Wichita Nat'l Bank, 352 S.W.2d 781, 783 (Tex. Civ. App.-Fort Worth 1961, writ ref'd n.r.e.) (while determining the enforceability of a conveyance of a beneficiary's expectancy, the court stated, "We think it is neither unreasonable nor unusual for children to agree to share equally in their parent's estate, even where some know or believe they would receive more than an equal share in a testamentary disposition.").

5 Unless the context otherwise requires, the term "testator" is used in a non-sex specific manner. See Webster's Ninth New Collegiate DICTIONARY 1219 (1987) (defining "testator" as "a person who dies leaving a will" (emphasis added)). expenditures limited to certain items (e.g., health care, room and board, and education) or with lump-sum distributions authorized only upon the beneficiary's fulfilling certain criteria (e.g., graduating from college or reaching a certain age). Although the trust may treat all of the testator's children equally, the imposition of restrictions may give the beneficiaries reason to contest the will and, if successful, immediately obtain the estate funds via intestacy without limitations or conditions.

\section{E. Elderly or Disabled Testator}

The age, health, mental condition, or physical capacity of a testator may provide unhappy heirs or beneficiaries of prior wills with a basis to claim lack of testamentary capacity or undue influence. Although the mere fact of advanced age, debilitating illness, or severe handicap does not necessarily diminish capacity, these circumstances can play an important role in supporting a will contest.

\section{F. Unusual Behavior of Testator}

A peculiar acting testator is apt to give dissatisfied heirs a basis for contesting the will either on the ground that the testator lacked capacity or was suffering from an insane delusion. Despite statements in Texas cases such as, "A man may believe himself to be the supreme ruler of the universe and nevertheless make a perfectly sensible disposition of his property, and the courts will sustain it when it appears that his mania did not dictate its provisions," 6 a will executed by a person with behavior or beliefs out of the mainstream of society's definition of "normal" is apt to trigger a contest action.

${ }^{6}$ Gulf Oil Corp. v. Walker, 288 S.W.2d 173, 180 (Tex. Civ. App.-Beaumont 1956, no writ) (quoting Fraser v. Jennison, 42 Mich. 206, 3 N.W. $882,900(1879))$. 
Caveat: This article discusses a wide range of techniques which may be helpful in preventing will contests. These techniques vary widely in both cost and predictability of results. There is no uniform approach to use for all clients. Each case needs to be carefully examined on its own merits before deciding which, if any, of the techniques should be used.

\section{INCLUDE IN TERROREM PROVISION}

An in terrorem provision, also called a nocontest or forfeiture clause, provides that a beneficiary who contests the will loses all or most of the benefits given under the will. In terrorem provisions are one of the most frequently used contest prevention techniques. This widespread use is probably due to the technique's low cost (a few extra lines in the will), low risk (no penalty incurred if clause declared unenforceable), and potential for effectuating the testator's intent (property passing via the will rather than through intestacy or under a prior will). ${ }^{7}$

\section{A. Validity and Enforceability}

Ever since dicta in Calvery v. Calvery, ${ }^{8}$ there has been uncertainty in Texas as to whether a no contest clause would be enforced to cause a beneficiary who contests a

7 See generally THOMAS E. ATKINSON, HANDBOOK OF THE LAW OF WILLS 408-10 (2d ed. 1953); 5 William J. Bowe \& Douglas H. PARKER, PAGE ON THE LAW OF Wills $\S 44.29$ (1962); William M. MCGOVERN, JR., ET AL., WILLS, TRUSTS AND ESTATES 585-88 (1988); W. Harry Jack, No-Contest or In Terrorem Clauses in Wills - Construction and Enforcement, $19 \mathrm{Sw}$. L.J. 722 (1965); Annotation, Validity and Enforceability of Provision of Will or Trust Instrument for Forfeiture or Reduction of Share of Contesting Beneficiary, 23 A.L.R.4th 369 (1983); 74 TeX. JuR. 3d Wills § 255 (1990).

855 S.W.2d 527, 530 (Tex. 1932, opinion adopted). will to forfeit his or her gift if the beneficiary had both (1) probable cause for bringing the action and (2) was in good faith in bringing and maintaining the action. The 2009 Legislature resolved this issue by codifying the good faith with probable cause exception to the enforceability of in terrorem provisions in Probate Code $\S 64$. The 2011 Legislature revised the exception to good faith with just cause. ${ }^{9}$

It is important to note that $\S 64$ only applies to the estates of decedents who died on or after the date of enactment, that is, June 19, 2009. Thus, the existence of this exception remains unclear with respect to estates of testators who included no contest provisions in their wills and who died before June 19, 2009.

Some testators may wish to trigger a forfeiture even if their wills are contested with probable cause and in good faith. Before the statute, these testators would state their intent and there was a good chance the court would carry out their intent. The new statute makes this approach problematic. Perhaps a "reverse" approach would work such as, "If X does not contest this will, X receives [gift]." In other words, the provision does not take something away if a contest occurs (no forfeiture) but rather provides a gift if the person does not contest the will (a reward). Instead of a condition subsequent (taking away something already given if the condition is breached, that is, a forfeiture), this type of provision imposes a condition precedent giving something if a condition is satisfied.

9 To be consistent with new Probate Code $\S 64$, the 2009 Legislature enacted Trust Code $\S 112.038$ which provides that a no contest clause is unenforceable if (1) probable cause exists for bringing the action and (2) the action was brought and maintained in good faith. The 2011 Legislature changed the exception to good faith with just cause. The unenforceability of in terrorem provisions under these circumstances cannot be changed by the settlor under Trust Code $\S 111.0035(\mathrm{~b})(6)$. 


\section{B. Drafting Guidelines}

There are no formal requirements for in terrorem provisions. Memorializing the testator's intent with clear and unambiguous language is the drafter's foremost consideration because in terrorem clauses are strictly construed. ${ }^{10}$

\section{Create Substantial Risk}

For an in terrorem provision to deter a will contest effectively, it must be carefully drafted to place the disgruntled beneficiary at significant risk. The clause should make the beneficiary think, "Do I keep quiet and get a sure thing (although less than I would get by intestacy or a prior will), or do I contest the will and risk receiving nothing?" In other words, the testator hopes that the beneficiary will follow the "one in the hand is worth two in the bush" philosophy. The clause must place the beneficiary in this dilemma and thus it is vital that the potential contestant's gift be large enough to elicit a genuine fear of contesting the will.

For example, assume that $\mathrm{X}$, a married person with two children from a former marriage, anticipates a distributable separate personal property estate of $\$ 300,000$. If $X$ dies without a valid will, the spouse and each child will receive $\$ 100,000$ via intestacy. ${ }^{11}$ X's wishes are, however, considerably different; $X$ desires to leave the bulk of the estate to the children. If $X$ leaves nothing to the spouse, or only a nominal amount, e.g., $\$ 5,000$, an in terrorem provision will have little impact on the spouse because the spouse gains tremendously if the will is invalid and loses little if the will and accompanying in terrorem provision are upheld. However, if X leaves the spouse a substantial sum, e.g., $\$ 50,000$, the spouse will hesitate to forfeit a guaranteed $\$ 50,000$, in addition to incurring

10 See generally W. Harry Jack, No-Contest or In Terrorem Clauses in Wills - Construction and Enforcement, 19 Sw. L.J. 722, 735-36 (1965).

11 TeX. Prob. Code $\S 38(\mathrm{~b})$. court costs and legal fees, for fear of taking nothing if the will is upheld, even though the spouse would receive a $\$ 100,000$ intestate share if the will is invalidated.

\section{Describe Triggering Conduct}

The in terrorem clause should indicate the conduct triggering forfeiture. Does the testator wish to prevent only a will contest or is the intent to prohibit a broader range of conduct? Will forfeiture occur upon the filing of a contest action or must actual judicial proceedings first occur? Is an indirect attack (e.g., where a beneficiary assists another person's contest) punishable the same as a direct attack? Will a contest by one beneficiary cause other beneficiaries to forfeit their gifts (e.g., five beneficiary/heirs are left a significant sum but less then intestacy, one of them agrees to take the risk of contest because the other four secretly agree to make up the loss if the contest fails)? Will a beneficiary's challenge to the appointment of the designated executor trigger forfeiture?

\section{Indicate Beneficiary of Forfeited Property}

The testator should name the recipient of the property that is subject to forfeiture under an in terrorem provision. This is especially important because the beneficiaries involved in will contests are often the testator's children. If a child forfeits a gift due to the application of the in terrorem clause, the contestant's children could argue that the gift passes to them because of the anti-lapse statute, i.e., the forfeited property should pass as if the contestant predeceased the testator. ${ }^{12}$ If this argument were to prevail, the forestalling effect of the clause would be limited. (In some jurisdictions, a gift over is a prerequisite to validity. ${ }^{13}$ )

Indicating the beneficiary of forfeited property has an additional benefit - it provides someone with a strong interest in

\footnotetext{
12 TeX. PRoB. CODE $§ 68$.

13 See GA. CODE $§$ 53-2-107(b) (1997).
} 
upholding the will. This contingent beneficiary, especially if it is a large charity capable of eliciting the support of the Texas Attorney General, may be able to place significant resources into fighting the contest. ${ }^{14}$

\section{Sample Provisions}

Caveat: The samples provided in this section are only examples, they are not recommendations. The uncertainties which exist regarding in terrorem clauses make it difficult to predict the result of using any particular language. In addition, an attorney should tailor in terrorem provisions to fit the particular situation.

\section{Simple Provision With Gift Over}

If any beneficiary under this Will contests or challenges this Will or any of its provisions in any manner, be it directly or indirectly, all benefits given to the contesting or challenging beneficiary under this Will are revoked and those benefits are given to [name of alternative beneficiary] [individuals who would take if the contesting beneficiary had predeceased me without descendants who survive me].

\section{Simple Provision With Nominal Gift to Contestant}

Any person who contests or challenges this Will for any reason either directly or indirectly, overtly or covertly, shall receive, instead of the portion or property given to him or her by this Will, the sum of ten dollars.

\section{Detailed Provision}

It is my will and I expressly provide and make it a condition precedent to the taking, receiving, vesting or enjoying

14 See Jeffrey L. Crown, Thwarting the Will Contest, in STATE BAR of TeXas, Advanced Estate PlanNing \& PRobate L7 (1985). of any property, benefit or thing whatsoever under and by virtue of this Will, that no beneficiary shall in any manner contest the probate of this Will, or question or contest this Will or any part or clause thereof in any judicial proceeding. Should any beneficiary so contest or question, or in any manner aid in a contest or questioning, the beneficiary shall lose and forfeit all right to any benefit and all right or title to any property, or thing herein directly or indirectly devised or bequeathed to the beneficiary; and every such right, title, property or thing shall vest in any of my beneficiaries as do not so question or contest or give aid in such questioning or contesting of this Will or the probate, or any clause or provision thereof, in the same proportion as to value in which they otherwise take in value of my estate under this Will. ${ }^{15}$

\section{EXPLAIN REASONS FOR DISPOSITION}

An explanation in the will of the reasons motivating particular dispositions may reduce will contests. For example, a parent could indicate that a larger portion of the estate is being left to a certain child because that child is mentally challenged, requires expensive medical care, supports many children, or is still in school. If the testator makes a large charitable donation, the reasons for benefiting that particular charity may be set forth along with an explanation that family members have sufficient assets of their own. The effectiveness of this technique is based on the assumption that disgruntled heirs are less likely to contest if they realize the reasons for receiving less than their fair (intestate) share.

It is possible, however, for this technique to backfire. The explanation may upset some

15 This provision is adapted from In re Estate of Minnick, 653 S.W.2d 503, 507, n.3 (Tex. App.-Amarillo 1983, no writ). 
heirs, especially if they disagree with the facts or reasons given, and thus spur them to contest the will. Likewise, the explanation may provide the heirs with material to bolster claims of lack of capacity or undue influence. For example, assume that the testator's will states that one child is receiving a greater share of the estate because that child frequently visited the aging parent. Another child may use this statement as evidence that the visiting child unduly influenced the parent. If the explanation is factually incorrect, heirs may contest on grounds ranging from insane delusion to mistake or assert that the will was conditioned on the truth of the stated facts. ${ }^{16}$

The language used to explain reasons for a disposition must be carefully drafted to avoid encouraging a will contest or creating testamentary libel. An alternative approach is to provide explanations in a separate document which could be produced in court if needed to defend a will contest, but which would not otherwise be made public. ${ }^{17}$

\section{AVOID BITTER OR HATEFUL LANGUAGE}

\section{A. Encourages Will Contests}

If the drafter decides it is advisable to explain the reasons for a particular dispositive scheme, care must be exercised to ensure the explanation does not have the opposite result, i.e., provoking a contest action attributable solely to the will's language. Any explanation of gifts or descriptions of heirs should be even-handed, free of bitterness or spite, and factually correct. An heir who feels slighted both emotionally and monetarily may be more likely to contest than one who is hurt only financially.

16 See generally Steve R. Akers, Anatomy of a Texas Will and Effective Will Drafting, in STATE BAR OF TEXAS, WILl DRAFTING D-104 (1989).

17 See infra $\S \mathrm{X}$, page 25.

\section{B. Potential for Testamentary Libel}

"To my grandson . . I give ... Ten

Dollars ... I have already given my said grandson the sum of One

Thousand Dollars ... which he squandered. This provision... expresses the regard in which I hold my said grandson, who deserted his mother and myself by taking sides against me in a lawsuit, and because he is a slacker, having shirked his duty in World War II."18

Testamentary libel may become an issue when a will containing libelous statements is probated and thereby published in the public records. Typically, such situations arise when testators explain their reasons for making, or not making, particular gifts. The question is then presented whether the defamed individuals are entitled to recover from the testator's estate or the executor.

No Texas case addressing testamentary libel was located. The conclusions of other jurisdictions addressing the issue vary. Some jurisdictions simply delete the offensive material from the probated will, while others hold the estate liable for the damages caused by the libelous material. Another group of jurisdictions, however, rule that there is no cause of action for testamentary libel because statements relating to judicial proceedings are privileged or because actions for personal injuries against the testator died along with the testator. ${ }^{19}$

Because Texas has not addressed this area of law, one should exercise care to avoid being the "case of first impression." An estate

18 Kleinschmidt v. Mattheiu, 266 P.2d 686, 687 (Or. 1954).

19 See William L. Prosser, Handbook of THE LAW OF TORTS $\S 113$ at 770-71 (4th ed. 1971); 80 AM. JR. 2d Wills § 873 (1975); Leona M. Hudak, The Sleeping Tort: Testamentary Libel, 12 CAL. W.L. REV. 491 (1976); A.L. Schwartz, Annotation, Libel by Will, 21 A.L.R.3d 754 (1968). 
planner should not draft a will containing libelous material. In addition, caution should be exercised in probating a libelous will and in serving as the executor for the estate.

\section{USE HOLOGRAPHIC WILL}

Wills entirely in the testator's own handwriting appear to have an aura of validity because they show the testator was sufficiently competent to choose his or her own words explaining intent and to write them down without outside assistance. The attorney may use this somewhat liberal tendency toward holographic wills to good advantage if the attorney anticipates a will contest. Before executing a detailed attested will, the testator could hand write a will which, although not as comprehensive as the formal will, contains a disposition plan preferred to intestacy. If the attested will was invalidated, the holographic will could serve as an unrevoked prior will.

\section{ENHANCE TRADITIONAL WILL EXECUTION CEREMONY}

One of the most crucial stages of a client's estate plan is the will execution ceremony the point at which the client memorializes his or her desires regarding at-death distribution of property. Unfortunately, attorneys may handle this key event in a casual or sloppy fashion. There are even reports of attorneys mailing or hand-delivering unsigned wills to clients along with will execution instructions. ${ }^{20}$ Some attorneys may allow law clerks or paralegals to supervise a will execution ceremony. This practice is questionable not only because it raises the probability of error, but because the delegation of responsibility may be considered a violation of professional conduct

20 See Hamlin v. Bryant, 399 S.W.2d 572, 575 (Tex. Civ. App.-Tyler 1966, writ ref'd n.r.e.). rules proscribing the aiding of a non-lawyer in the practice of law. ${ }^{21}$ An unprofessional or unsupervised ceremony may provide the necessary ammunition for a will contestant to successfully challenge a will. This section suggests a comprehensive step-by-step format for a proper will execution ceremony under Texas law which can provide economical "will insurance" for every testator. ${ }^{22}$

\section{A. Prior to the Ceremony}

\section{Proofread Will}

Before the client arrives for the will execution ceremony, the attorney should carefully proofread the will for errors such as misspellings, omissions, erasures, and overstrikes. To reduce the number of inadvertent errors, it is advisable for another attorney to review the will. All errors should be carefully corrected and a new original prepared; interlineations, mark-outs, erasures, and correction fluids should not be used.

\section{Assure Internal Integration of Will}

The attorney should inspect the will to ensure that all pages are typed or printed on the same kind of paper, all pages are the same size, the font types and sizes are consistent throughout the will, each page is numbered ex toto (e.g., page 4 of 10), and there are no excessive blank spaces.

The pages of the will need to be securely fastened together, but it is a good idea to wait

21 See Palmer v. Unauthorized Practice Comm. of the State Bar, 438 S.W.2d 374, 376 (Tex. Civ. App.-Houston [14th Dist.] 1969, no writ); Gerry W. Beyer, The Role of Legal Assistants in the Estate Planning Practice, EST. PLAN. DEV. FOR TEX. Prof., April 1989, at 1, 2-3. See generally Gail E. Cohen, Using Legal Assistants in Estate Planning, PRAC. LAW., Oct. 15, 1984, at 73; Robert S. Mucklestone, The Legal Assistant in Estate Planning, 10 REAL PROP. ProB. \& TR. J. 263 (1975).

22 See Gerry W. Beyer, The Will Execution Ceremony - History, Significance, and Strategies, 29 S. TEX. L. REV. 413 (1988) (portions of $\S$ VI are adapted from this article). 
until after the client has reviewed the will to facilitate any last minute changes or corrections. If the pages of the will are stapled, the staples should not be removed once inserted; multiple staple holes may be evidence of improper page substitution. ${ }^{23}$

\section{Review Will With Client}

The attorney should review the final draft of the will with the client to confirm that the client understands the will and that it comports with the client's intent. The client should have adequate time to read the will to ascertain that corrections to prior drafts have been made and to determine that no unauthorized provisions have inadvertently crept into the will.

\section{Explain Ceremony to Client}

The attorney should explain the mechanics of the will execution ceremony to the testator in language the testator understands. Legal jargon should be avoided because the client may be too embarrassed to admit a lack of understanding. It is helpful for the client to know how the ceremony will proceed and what is expected, e.g., to answer certain questions.

\section{B. The Ceremony}

\section{Select Appropriate Location}

The will execution ceremony should take place in pleasant surroundings. A conference room works well, as does a large office with appropriate tables and chairs. The client should be comfortable and at ease during the ceremony. A relaxed client is more likely to present a better image to the witnesses.

\section{Avoid Interruptions}

The ceremony should be free of interruptions. Thus, secretaries should hold all telephone calls and be instructed not to interfere with the ceremony. Once the

23 See Mahan v. Dovers, 730 S.W.2d 467, 469 (Tex. App.-Fort Worth 1987, no writ). ceremony begins, no one should enter or leave the room until the ceremony is completed. Interruptions disrupt the flow of the ceremony and may cause the supervising attorney to inadvertently omit a key element.

\section{Gather Participants}

The testator, two or three disinterested witnesses, a notary, and the supervising attorney should be gathered at the appropriate location. As a precaution against claims of overreaching and undue influence, no one else should be present under normal circumstances.

\section{Seat Participants Strategically}

The participants need to be seated so each can easily observe and hear the others. The attorney should be conveniently located near the participants to make certain the proper pages are signed in the correct places.

\section{Make General Introductions}

The attorney should introduce all participants. Although it may be advisable to use witnesses already known to the client, ${ }^{24}$ it is a common practice for attorneys to recruit anyone who is around (e.g., secretary, law clerk, delivery person) to serve as the witnesses. Accordingly, it is important to impress the identity of the testator on the witnesses so they will be able to remember the ceremony should their testimony later be needed.

\section{Explain Ceremony}

The attorney should explain the importance of the will execution ceremony and that it is about to commence. Although Texas law does not require publication for a valid will, ${ }^{25}$ it is useful for the witnesses to know the type of document being witnessed.

${ }^{24}$ See infra § VIII, page 24.

25 Davis v. Davis, 45 S.W.2d 240, 241 (Tex. Civ. App.-Beaumont 1931, no writ). 
In addition, publication is required for the self-proving affidavit. ${ }^{26}$

\section{Establish Testamentary Capacity}

If the attorney anticipates a will contest, it is especially important to establish each element of testamentary capacity during the ceremony. The attorney and the testator should engage in a discussion designed to cover the elements of testamentary capacity as found in Texas cases such as Prather $v$. McClelland, ${ }^{27}$ i.e., the attorney should demonstrate that the testator knows the testator is executing a document disposing of the testator's property upon death, that the testator knows the general nature and extent of the testator's property and the natural objects of the testator's bounty, and that the testator is able to appreciate these things at the same time so as to make reasonable judgments.

\section{Establish Testamentary Intent}

Questions substantially in the following form should be directed to the testator to demonstrate testamentary intent.

- [Testator's name], is this your will?

- Have you carefully read this will and do you understand it?

- Do you wish to make any additions, deletions, corrections, or other changes to your will?

- Does this will dispose of your property at your death in accordance with your desires?

- Do you request [witnesses' names] to witness the execution of your will?

26 TEx. Prob. CoDE $§ 59$ (requiring witnesses to swear that testator said instrument is testator's last will and testament).

2776 Tex. 574, 584-85, 13 S.W. 543, 546 (1890).

\section{Conduct Will Execution}

The following steps should be followed when the testator executes the will.

- All writing on the will should be in blue ink to make an obvious distinction between the original and a photocopy. The will's testimonium and attestation clauses should indicate that the testator and the witnesses used blue ink.

- Testator initials each page of the will, except the last page, at the bottom or in the margin to reduce later claims of page substitution.

- Testator completes the testimonium clause by filling in the date and location of the ceremony.

- Testator signs the will at the end. The testator should sign as the testator usually does when executing legal documents to prevent a contest based on forgery. ${ }^{28}$

- The attorney should pay close attention to make certain everything is written in the proper locations.

- Although not a necessary element of a valid will under Texas law, the witnesses should watch the testator sign the will so that they may testify to the signing.

\section{Conduct Attestation by Witnesses}

The following procedure should be used for the witnesses' attestation assuming the

\footnotetext{
28 See In re Estate of Jernigan, 793 S.W.2d 88, 90 (Tex. App.-Texarkana 1990, no writ) (The testator signed the first letter of his name with a lower case letter rather than with an upper case letter as he had previously done on other documents. The evidence revealed that the testator sometimes signed documents, such as his driver's license, beginning with a lower case letter. The court found that the trial court's refusal to hold that the testator's name was forged was not against the great weight and preponderance of the evidence.).
} 
self-proving affidavit is not included as part of the will itself. ${ }^{29}$ If the affidavit is part of the will, the steps in $\S 12$ should be included at this point.

- One of the witnesses reads the attestation clause aloud to help impress the will execution ceremony on the minds of the witnesses.

- Each witness initials every page, except the page with the attestation clause, at the bottom or in the margin. This helps reduce claims of page substitution.

- One of the witnesses dates the attestation clause to provide additional evidence of when the execution occurred.

- Each witness signs the attestation clause and writes his or her address. Having this information on the will may be helpful should it later become necessary to locate the witnesses.

- The attorney carefully watches to make certain everything is written in the proper locations.

- The testator observes the witnesses signing the will. Although the testator is not required to see the witnesses sign, the attestation must take place in the testator's presence. ${ }^{30}$ The term presence has been defined as a conscious presence, i.e., "the attestation must occur where testator, unless blind, is able to see it from his actual position at the time, or at most, from such position as slightly altered, where he has the power readily to

29 As of September 1, 2011, the self-proving language may be included within the body of the will so that only one set of signatures is required. Tex. Prob. CODE. § 59(a-1).

30 Tex. Prob. Code $\S 59$. make the alteration without assistance." 31

- The witnesses observe each other signing. Although this is not required under Texas law, the witnesses will provide better testimony concerning the ceremony if they observe each other signing the will.

\section{Declare Will Executed}

After the attestation is finished, the attorney should declare that the will is executed. A clear demarcation between the actual will ceremony and the completion of the self-proving affidavit is important because a proper will is a prerequisite to an effective self-proving affidavit when the self-proving affidavit is a separate document.

As of September 1, 2011, the self-proving language may be included within the body of the will so that only one set of signatures is required. ${ }^{32}$

\section{Complete Self-Proving Affidavit}

The completion of the self-proving affidavit, whether as a separate document or as part of the will itself, should include the following steps.

- The attorney explains the purpose and effect of a self-proving affidavit, i.e., to make probate easier and more efficient by allowing the will to be admitted without the testimony of witnesses. ${ }^{33}$

31 Nichols v. Rowan, 422 S.W.2d 21, 24 (Tex. Civ. App.-San Antonio 1967, writ ref'd n.r.e.); see also Morris v. Estate of West, 643 S.W.2d 204, 206 (Tex. App.-Eastland 1982, writ ref'd n.r.e.) (attestation deemed to be outside of testator's presence because testator could not have seen witnesses sign without walking four feet to office door and fourteen feet down a hallway).

32 Tex. Prob. Code. § 59(a-1).

33 Tex. Prob. Code $\S 59$. 
- The notary takes the oath of the testator and witnesses. ${ }^{34}$

- The notary asks the testator to answer the following questions: ${ }^{35}$

- [Testator], is this document your last will and testament?

- Have you willingly made and executed your will?

- Did you do so as your free act and deed?

- The notary asks the witnesses to answer the following questions: ${ }^{36}$

- Did [testator] declare to you that this is his/her last will and testament?

- Did [testator] execute this document as his/her last will and testament?

- Did [testator] want [witnesses] to sign it as witnesses?

- Did you sign the will as a witness?

- Did you sign the will in [testator's] presence?

- Did you sign the will at the request of [testator]?

- Was [testator] at the time of will execution eighteen years

34 See Broach v. Bradley, 800 S.W.2d 677 (Tex. App.-Eastland 1990, writ denied) (selfproving affidavit invalid because notary had not properly sworn the witnesses).

35 These questions are modeled after the statutory form. TeX. Prob. CODE § 59. Having the testator answer questions impresses the ceremony on the witnesses better than if the testator is merely asked to read and sign the affidavit.

36 These questions are modeled after the statutory form. TEX. PROB. CODE §59. Having the witnesses answer questions impresses the ceremony on the witnesses better than if they are merely asked to read and sign the affidavit. of age or over (or being under such age, was or had been lawfully married, or was then a member of the armed forces of the United States or of an auxiliary thereof or of the Maritime Service)?

- Was [testator] of sound mind?

- Are you at least fourteen years of age?

- The testator and witnesses sign the affidavit.

- The attorney carefully watches to make certain everything is written in the proper locations. The selfproving affidavit will have no effect if signatures on the affidavit are needed to prove the will. ${ }^{37}$

- The notary signs the affidavit and affixes the appropriate seal or stamp.

- The notary records the ceremony in the notary's record book. ${ }^{38}$

\section{Conclude Ceremony}

The attorney should indicate that the will execution ceremony is now completed. If other estate planning documents, such as a directive to physician, self-declaration of guardian, or durable power of attorney, are needed in the estate plan, it is convenient to execute them at the same time because these documents often require witnesses or selfproving affidavits.

37 TeX. PRob. Code $§ 59$ (“A signature on a self-proving affidavit $* * *$ is considered a signature to the will if necessary to prove that the will was signed by the testator or witnesses, or both, but in that case, the will may not be considered a self-proved will."). Note that under prior law, the will failed if the witnesses' signatures were misplaced on some other document such as the self-proving affidavit. See, e.g., Wich v. Fleming, 652 S.W.2d 353, 355 (Tex. 1983); Boren v. Boren, 402 S.W.2d 728, 729-30 (Tex. 1966).

38 TEX. GOv’T CODE $§ 406.014$. 


\section{After the Ceremony}

\section{Confirm Testator's Intent}

The attorney should talk with the testator to confirm that the testator understood what just happened and that the testator does not have second thoughts about the disposition plan.

\section{Make Copies of Will}

The attorney should retain a photocopy of the executed will so that the attorney may review it on a periodic basis to determine whether revisions are needed due to a change in the law or testator's circumstances. In addition, the copy of the executed will is useful evidence of the will's contents if the original cannot be produced after death and there is sufficient evidence to overcome the presumption of revocation. ${ }^{39}$

\section{Discuss Safekeeping of Original Will}

Determining the proper custodian of the original will is a difficult task and an anticipated contest makes it even more difficult. It is important to store the original will in a secure location where it may be readily found after the testator's death. Thus, some testators elect to keep the will at home or in a safe deposit box, and others prefer for the attorney to retain the will. In the normal situation, an attorney should refrain from suggesting to retain the original will because the original is then less accessible to the testator. Consequently, the testator may feel pressured to hire the attorney to change the will and the executor or beneficiaries may feel compelled to hire the attorney to probate the will. Some courts in other jurisdictions hold that an attorney may retain the original will only "upon specific unsolicited request of the

39 See Mingo v. Mingo, 507 S.W.2d 310, 311 (Tex. Civ. App.-San Antonio 1974, writ ref'd n.r.e.) (unlocated will presumed revoked if it was in possession of testator when last seen); TEX. PROB. CODE $\S 85$ (requirements to prove a written will not produced in court). client."40 If a will contest is likely, however, it may be dangerous to permit the client to retain the will because the will then stands a greater chance of being located and destroyed or altered by the heirs. An attorney may need to urge the testator to find a safe storage place that will not be accessible to the heirs, either now or after death, but yet a location where the will may be found and probated, while taking care not to urge that the attorney act as the will's sanctuary. The executor named in the will, especially if the executor is a nonfamily member/non-beneficiary or a corporate fiduciary, may be able to provide such a safe haven for the will.

\section{Destroy or Preserve Prior Will}

When a new will is executed, it is common practice to physically destroy prior wills. If the testator's capacity is in doubt, however, and the testator indicates a preference for the prior will compared to intestacy, it is a good idea to retain the prior will. If a court holds that the new will is invalid, the attorney may offer the old will for probate much to the chagrin of the contestant. ${ }^{41}$

\section{Provide Testator With Post-Will Instructions}

The attorney should provide the testator with a list of post-will instructions containing at least the following:

- Discussion of the need to reconsider the will should the testator's life or circumstances change due, for example, to births or adoptions, deaths, divorces, marriages, change in feelings toward beneficiaries and heirs, significant changes in size or composition of estate, or change in state of domicile.

- Explanation that mark-outs,

40 State v. Gulbankian, 196 N.W.2d 733, 736 (Wis. 1972).

41 See Leon Jaworski, The Will Contest, 10 BAYLOR L. REV. 87, 95 (1958). 
interlineations, and other informal changes are usually insufficient to change the will. ${ }^{42}$

- Instructions regarding safekeeping of the original will.

- Statement that the will must be reviewed if relevant state or federal tax laws change.

\section{MEMORIALIZE WILL EXECUTION CEREMONY ON VIDEO}

Modern video-recording technology provides an inexpensive, convenient, and reliable type of "will insurance" which preserves evidence of the will execution ceremony and its important components, such as the condition and appearance of the testator and the presence of witnesses, along with an accurate reproduction of the exact document which was signed. ${ }^{43}$ Although videorecording the will execution ceremony is not common practice, the potential of this technique must not be overlooked. This section begins by detailing the possible uses of a video-recording of the will execution ceremony and the status of the law with regard to the video's admissibility into

\footnotetext{
42 See Leatherwood v. Stephens, 24 S.W.2d 819 (Tex. Comm'n App. 1930, judgment adopted).

43 For further information about videotaping the will execution ceremony, see Gerry W. Beyer, Videotaping the Will Execution Ceremony Preventing Frustration of the Testator's Final Wishes, 15 ST. MARY's L.J. 1 (1983); Gerry W. Beyer, Video Requiem: Thy Will be Done, TR. \& EsT., July 1985, at 24; Gerry W. Beyer, Videotaping the Will Execution Ceremony, Est. Plan. Stud., Oct. 1989, at 1 from which portions of this section are adapted; Gerry W. Beyer \& William R. Buckley, Videotape and the Probate Process: The Nexus Grows, 42 OKLA L. REV. 43 (1989); William R. Buckley \& Alfred W. Buckley, Videotaping Wills: A New Frontier in Estate Planning, 11 OHIO N.U.L. REV. 271 (1984); Jodi G. Nash, A Videowill: Safe and Sure, A.B.A. J., Oct. 1984, at 87.
}

evidence. The advantages and disadvantages of preparing such a video-recording are examined, followed by a discussion of the video-recorded ceremony itself which includes the major elements needed to fully utilize the advantages of this innovative technique.

\section{A. Uses of Will Execution Video-recording}

A meticulously prepared video, recording both the visual and audio aspects of the will execution ceremony, may prove indispensable should a will contest arise. This procedure provides the testator with greater assurance that upon the testator's death the will shall take effect and operate as anticipated. Moreover, the video-recording eases the court's task of determining whether the requirements for a valid will were satisfied.

\section{Establishes Testamentary Capacity}

The testator may answer questions on the video designed to clearly and convincingly demonstrate each element of testamentary capacity. Below are some examples.

- The testator must understand that the testator is executing a will. The testator's statements in front of a video camera regarding the nature of the act about to be performed provides strong evidence of such an understanding.

- The testator must also understand the effect of making a will. The testator's recorded explanation that the testator is making a will to provide for the distribution of the testator's property upon death would demonstrate this requirement.

- The testator must comprehend the general nature and extent of the testator's property. The videorecording can show the testator describing the testator's property and estimating its value. 
- The testator must realize who is entitled to the testator's property should the testator die without a will. The testator can discuss the details of the testator's family situation on the video thereby avoiding claims that the testator was unaware of the natural objects of the testator's bounty.

- The testator must be able to appreciate simultaneously what the testator is doing, the testator's property, and the testator's family situation so the testator may form a coherent plan for the distribution of the testator's estate. A video of the testator discussing the testator's will, explaining the testator's situation, and executing the will would tend to prove this important element.

\section{Shows Due Execution of Will}

A video-recording of the will execution ceremony provides proof that all of the technical requirements for a valid will were satisfied. The video can show the testator declaring the document to be the testator's will and affixing the testator's signature, and the witnesses observing the will execution and thereafter signing in the conscious presence of the testator.

\section{Demonstrates Testamentary Intent}

The document which allegedly constitutes the testator's will fails unless it can be demonstrated that it is the very instrument by which the testator intended to make a posthumous disposition of the testator's property. The video-recording of the will execution ceremony would show both the testator and the will itself. Thus, the video would provide theoretically irrebuttable evidence that the document claimed to be the testator's will was the same document executed during the ceremony.

\section{Shows Contents of Will}

In many situations, it may be difficult to determine the contents of a written will. For example, the testator may have inadvertently lost or destroyed the original will or have hidden it so well that the survivors are unable to locate it. Even if the actual will is produced at probate, portions of it may be missing, erased, or illegible. A video provides excellent evidence of the will's contents by showing the testator reading the entire will aloud and by reproducing the will itself on video so it may be read. The recording may also include close-ups of the testator and witnesses initialing each page of the will so that claims of page substitution may be rebutted.

\section{Establishes Lack of Undue Influence or Fraud}

The video-recording affords the testator with the opportunity to explain that the will is voluntarily made as an act of free will and not as a result of undue influence or fraud. This is particularly important where an unusual disposition is made, such as the disinheritance of a spouse or child.

\section{Assists in Will Interpretation and}

\section{Construction}

Statements made by the testator contemporaneous with the will execution could prove very helpful in determining the correct interpretation and construction of various provisions of the will. By explaining what the testator means by certain words and phrases, the testator can preserve evidence of the testator's intent which would prove invaluable should a dispute later arise.

\section{B. Admissibility of Will Execution Video- recording}

\section{In General}

The admissibility of a video-recording depends generally on the following considerations: (1) relevance; (2) fairness and accuracy; (3) the exercise of judicial 
discretion as to whether the probative value of the recording outweighs the prejudice or possible confusion it may cause; and (4) other evidentiary considerations such as the presence of hearsay. ${ }^{44}$ A video of the will execution ceremony may easily be admitted under these standards. A video is not subject to the vagaries of a witness' fading memory, and it presents a more comprehensive and accurate view of the testator and the testator's condition at the time of will execution than does a piecemeal tendering into evidence of witnesses' testimony.

Although jurisdictions differ and courts do not always enumerate a complete list of foundation elements, there is basic agreement that seven elements must be established before a video-recording may be admitted into evidence. 45 Not all judges insist that the party wishing to use a video of the will execution ceremony satisfy each of these elements, but most courts require a showing of unaltered recording, visual and audio clarity, and sufficient identification of the speakers. The key factor in determining admissibility appears to be that the video is a true and accurate representation of the events portrayed.

The elements of a proper predicate are as follows:

\section{a. Proper Functioning of Equipment}

The proponent of the video must show that the recording equipment and the recording medium (tape, DVD, memory chip, hard drive, etc.) were in proper working order at the time of the recording so that both audio and visual events were accurately recorded. The operator of the equipment is the most likely individual to provide this testimony.

44 See generally 3 CHARLES E. SCOTT, Photographic EVIDENCE $§ 1294$ (2d ed. 1969 \& Supp. 1994).

45 See, e.g., Allen v. State, 247 S.E.2d 540, 541 (Ga. Ct. App. 1978); Roy v. State, 608 S.W.2d 645, 649 (Tex. Crim. App. 1980); State v. Hewett, 545 P.2d 1201, 1204 n.4 (Wash. 1976).

\section{b. Equipment Operator Competency}

The operator of the recording equipment must be competent. It is not necessary to show that the operator was an expert provided the operator had sufficient skill to run the equipment properly.

\section{c. Accuracy of Recording}

It must also be established that the recording truly and correctly depicts the events and persons shown. The video portion should be properly focused and the audio portion should be sufficiently loud and clear so that it is understandable and not misleading.

\section{d. Proper Preservation of Recording}

The video must have been appropriately preserved. A detailed record of the chain of custody of the recording is often helpful.

\section{e. Lack of Alteration}

A showing must be made that the recording has not been altered; no changes, additions, or deletions are allowed. The testimony of someone present during the recording may be used to establish this element as well as the testimony of an expert who has physically and electronically inspected the media for tampering.

\section{f. Accurate Identification of Participants}

The recorded individuals need to be accurately identified. This should be an easy task because both visual and audio clues are available. Although an extremely competent actor could deceive audio and visual senses, individuals familiar with the parties should be able to spot an impostor.

\section{g. Tape Voluntarily Made}

It must also be shown that the recording was voluntarily made without improper inducement. The fact that a testator videorecorded the execution of the testator's will is usually indicative of the voluntary nature of the recording. The recording may portray the 
entire setting dispelling claims that the recording was made involuntarily. Of course, someone out of camera range could threaten the testator with a gun, hold the testator's family hostage, or threaten to withhold food and medicine.

\section{Via Court Decision}

\section{a. United States Generally}

Despite the increasing availability and popularity of video-recording the will execution ceremony, there are only a few reported cases discussing the use of video in probate actions. The earliest case located was a 1979 Florida case. ${ }^{46}$ In affirming the trial court's decision that the appellee had not exercised undue influence over the testator, this court merely mentioned that the record in the case showed that the testator's attorney had arranged for the videotaping of the will execution ceremony. The court did not specifically discuss the contents of the videotape. In a 1984 Alabama case, the court discussed how the testator explored the possibility of having his will videotaped but was advised by his attorney to undergo a psychiatric examination instead. ${ }^{47}$ In an unreported case, an Ohio court indicated that an attorney was not responsible for will contest litigation costs for failing to videotape the will execution ceremony. ${ }^{48}$ In a 1990 Kansas case, the court mentioned that there was evidence that the will execution ceremony had been taped but that the tape was probably destroyed by the attorney's "overzealous" brother-in-law after both the drafting attorney and the testator had died. 49

46 Estate of Robertson v. Gallagher, 372 So. $2 d$ 1138, 1140-42 (Fla. Dist. Ct. App. 1979). 1984).

47 Wall v. Hodges, 465 So. 2d 359, 661 (Ala.

48 In re Estate of Nibert, 1988 WL 102420 (Ohio App.).

49 In re Estate of Raney, 799 P.2d 986, 989-90 (Kan. 1990).
Four cases from the late 1980s directly involve videotapes of the will execution ceremony. In each of these cases, the videotape was carefully examined by the court and then used as evidence to determine the testator's capacity or the presence of undue influence. The first of these cases was decided in 1986 by an Oklahoma appellate court. 50 The videotape showed the testator as well as the conduct of various individuals involved with the will execution ceremony. This recording was one of the factors the court cited as supporting a prima facie showing of undue influence.

In a 1987 Delaware case, ${ }^{51}$ the testatrix executed two wills, both videotaped, as well as a non-videotaped codicil to the latter will. The judge found that a long addiction to alcohol had so impaired the testatrix' mental faculties that she lacked capacity to make a valid will. The videotape of the first will execution ceremony established that it was necessary to remind the testatrix of the nature of her investments, and that despite the reminder, she failed to understand their nature. The videotape of the second will also showed that her attorney avoided any mention of her assets. In addition, the fact that the codicil was not videotaped appeared to support the judge's finding that the codicil was procured by undue influence.

In an unpublished opinion, ${ }^{52}$ an Ohio appellate court indicated that the most compelling evidence presented on the issue of testamentary capacity was a videotape of the will execution ceremony. The following discussion from the opinion is instructive.

That tape discloses a man near the end of his life suffering the debilitating

50 Estate of Seegers v. Combrink, 733 P.2d 418, 421-22 (Okla. Ct. App. 1986).

51 Stotlar v. Cook, 1987 WL 6091 (Del. Ch.), aff'd without opinion, 542 A.2d 358 (Del. 1988).

52 Trautwein v. O’Brien, 1989 WL 2149 (Ohio Ct. App.). 
effects of a series of severe strokes; a man who at times appears totally detached from the proceedings. Viewing the tape clearly reveals the testator's inability to comprehend all that was going on about him. Certainly, one would seriously question his ability to dispose of several million dollars in estate assets by means of a complicated will and trust arrangement. Further, it is apparent from the tape that the whole proceeding was directed and controlled by the decedent's attorney. [The testator's] total participation was prompted by the use of leading questions. The tape further shows that the decedent lacked an accurate understanding of the extent of his property and holdings, his estimates ranging from five to eight million dollars.

In a 1989 Nebraska case, the testatrix was videotaped discussing her distribution plan with her attorney and then executing a codicil to her will. ${ }^{53}$ The jury viewed the tape, heard other evidence, and then decided that the testatrix had capacity. The favorable finding on capacity was upheld by the Nebraska Supreme Court despite various difficulties with the tape. For example, the testatrix misstated her age by two years, made mistakes regarding the year her house burned down and the year her husband died, misstated the size of her ranch, and needed to be reminded about the identity of one of her sons. However, the tape showed that she was generally aware of her property and knew where all her sons lived and their occupations. She also explained why she was leaving more property to one of her sons. Some of the contestant's witnesses testified that during the taping the testatrix had her head down, eyes closed, and appeared to be asleep. Another witness stated she was reluctant to witness the codicil because she believed the testatrix did

53 Peterson v. Glinn, 439 N.W.2d 516 (Neb. 1989). not know what she was doing. Both the jury and the court indicated that the videotape, its faults notwithstanding, justified giving little weight to this testimony.

These decisions may, at first glance, appear somewhat disconcerting because the videotapes were used three out of four times to support findings of invalid wills. The lack of reported decisions in which the videotape bolstered will validity, however, does not reflect poorly on the value of videotaping the will execution ceremony. Instead, the scarcity of reported cases addressing videotaped will execution ceremonies in general, and specifically those using the tape to uphold the will, is likely due to one or more of the following factors.

- A sufficient basis already exists under current law to support the admissibility of a videotape of the will execution ceremony. Thus videotapes may be frequently used at the trial level to support a will in cases which are not reported or appealed.

- Because videotape was not used in the probate process until recently, many testators who have prepared a video have not died. Therefore, the available pool of videotape cases is relatively small.

- The mere existence of the videotape reduces litigation because potential will contestants are reluctant to proceed in the face of the strong evidence provided by the tape.

- Many individuals, already disturbed by the estate planning process and unpleasant thoughts about death, are fearful of the prospect of appearing on camera and thus may prefer to forego using videotape techniques.

- The failure of an attorney to prepare a videotape of the will execution ceremony under circumstances where the reasonably prudent 
attorney would do so does not lead to malpractice liability in Texas and most other jurisdictions; the lack of privity between the attorney and the intended beneficiaries bars the action. ${ }^{54}$

\section{b. Texas}

Hammers v. Powers 55 is the first Texas case to discuss, albeit briefly, the use of a will execution videotape to demonstrate that the testatrix had testamentary capacity and was not under undue influence. In this 1991 opinion, the court examined summary judgment evidence which included affidavits, depositions, and a videotape of the testatrix signing her will. The court found that this evidence established as a matter of law that she had capacity and was not unduly influenced.

In 1999, the court in In re Estate of Foster, ${ }^{56}$ had before it a case in which a videotaped will execution was introduced into evidence. The record reflected the testimony of one of the beneficiaries who originally challenged the testatrix's testamentary capacity who "stated that if the will had been read to [the testatrix] while the video tape was being made, he would not have objected to the will." 57

54 See Berry v. Dodson, Nunley \& Taylor, P.C., 717 S.W.2d 716, 718 (Tex. App.-San Antonio 1986), writ dism'd by agr., 729 S.W.2d 690 (Tex. 1987); Dickey v. Jansen, 731 S.W.2d 581, 582 (Tex. App.-Houston [1st Dist.] 1987, writ ref'd n.r.e.). See generally Roger M. Baron, The Expansion of Legal Malpractice Liability in Texas, 29 S. Tex. L. REV. 355, 361 (1987). Cf. In re Estate of Nibert, 1988 WL 102420 (Ohio App.) (indicating that an attorney was not responsible for will contest litigation costs for failing to videotape the will execution ceremony).

55819 S.W.2d 669 (Tex. App.-Fort Worth 1991, no writ).

563 S.W.3d 49 (Tex. App.-Amarillo 1999, no pet.).

57 Id. at 53 .

\section{Via Legislation}

Only two states currently have legislation specifically addressing the admissibility of a video recording of the will execution ceremony: Indiana ${ }^{58}$ and Louisiana. ${ }^{59}$

Several other state legislatures have considered bills expressly dealing with videotape and the probate process, but none of the bills have been enacted. During the 1985 session of the Texas Legislature, several bills were introduced relating to using a videotape of the will execution ceremony. ${ }^{60}$ These bills were uncomplicated, merely stating that the videotape would be admissible as evidence of the identity and competency of the testator and of any other matter relating to the will and its validity. In 1986, the New Jersey Legislature considered a bill allowing the use of videotape not only as an evidentiary tool but also as the will itself, provided a written transcript accompanied the videotape. ${ }^{61}$ The proposal was quite detailed, requiring the videotape to comply with a laundry list of requirements. In 1987, the New York Legislature debated a simple bill allowing a videotape of the will execution ceremony to be used to prove due execution, intent, capacity, authenticity, as well as any other facts that the court decided were relevant to the probate of the testator's will or the administration of the testator's estate. ${ }^{62}$

\section{Via Administrative Decision}

The Board of Commissioners on Grievances and Discipline of the Supreme

58 IND. CODE $§$ 29-1-5-3 (2000 \& Supp. 2009). See generally William R. Buckley, Indiana's New Videotaped Wills Statute: Launching Probate into the 21st Century, 20 VAL. U.L. REV. 83 (1985).

59 LA Code Civ. Proc. art. 2904 (Supp. 2010).

60 Tex. H.B. 247, 69th Leg. (1985); Tex. S.B. 732, 69th Leg. (1985).

61 H.B. 3030, 202d N.J. Leg., 1st yr. Sess. (1986).

62 S. Res. 5098, 210th N.Y. Leg. (1987-88). 
Court of Ohio has approved videotaping the will execution ceremony. In a 1988 opinion, the Board stated that "[v]ideotaping the reading and execution of a will is not prohibited under the Code of Professional Responsibility. The testator should be made aware, however, that the videotape is not meant to replace the written will." 63

\section{Advantages Over Other Types of Evidence}

A video-recording of the will execution ceremony has tremendous advantages over the use of other evidence.

\section{Accuracy}

An unaltered video is highly accurate. The recording reflects the events as they actually occurred during the execution ceremony thus eliminating the necessity of relying upon witnesses whose memories fade and whose impressions change with the passage of time. Likewise, the recording serves as the testator's personal statement of disposition desires without the intervention of an attorney or other scrivener.

\section{Improved Testator Evaluation}

The testimony of witnesses and the reading of a written will provide incomplete views of the subject under evaluation - the testator and the testator's last wishes. A video of the will execution ceremony preserves valuable non-verbal evidence such as demeanor, voice tone and inflection, facial expressions, and gestures. This type of evidence may be crucial to resolve such issues as testamentary capacity and freedom from undue influence.

\section{Deterrent to Will Contest Action}

A significant benefit of video-recording the will execution ceremony is the recording's ability to deter will contest actions. The testator is the key witness in an action to set

63 Bd. of Commn'rs on Grievances \& Discipline, Sup. Ct. of Ohio, 88-014 (1988). aside a will, but of course, the testator is unable to defend the testator's capacity or disposition desires when the testator's testimony is needed. Fortunately, the video can preserve this important testimony. It is especially important to prepare this evidence when the testator leaves property in an unusual manner (e.g., to a friend or charity to the exclusion of the testator's spouse or children) or when the testator has some type of disability which does not affect testamentary capacity but which may give unhappy heirs an incentive to contest (e.g., a testator who is blind, illiterate, or paralyzed by a stroke).

\section{Psychological Benefits}

"[F]acing the reality of death and its attendant consequences is one of the most difficult responsibilities in life."64 A videorecording of the will execution ceremony may help the testator, the testator's survivors, the court, and the jury better cope with this arduous task. The testator may feel more confident that the testator's desires will be carried out because the recording provides more substantial evidence of the testator's intent than the testator's written will alone. The survivors may gain solace from viewing the testator delivering the testator's final message - a loving last memory of the testator. Finally, the court and jury may be more likely to believe what they see and hear on a video than the courtroom testimony of interested persons. Thus, a will disinheriting a needy spouse or child is more likely to stand when the video clearly shows the testator's capacity and intent.

\section{Potential Problems}

Despite the significant benefits of preparing a video-recording of the will execution ceremony, there are several

64 Charles I. Nelson \& Jeanne M. Starck, Formalities and Formalism: A Critical Look at the Execution of Wills, 6 PePPERDINE L. REV. 331, 348 (1979). 
potential problems. Anyone contemplating using this technique must be aware of possible shortcomings. In some cases, steps may be taken to reduce or eliminate these problems, while in other situations the prudent decision would be not to prepare a video.

\section{Poor Appearance of Testator}

Although a situation may otherwise seem appropriate for video-recording the will execution ceremony, the attorney may be hesitant to expose the testator to the court. An accurate picture of the testator may lead a judge or jury to conclude that the testator was incompetent or unduly influenced. Similarly, bias against the testator may exist because of the testator's outward appearance; the testator's age, sex, race, disability, or perceived annoying habits may prejudice some individuals. 65

If the testator's appearance is poor, it may be advisable to forego video-recording the ceremony and use other contest avoidance techniques. If the video is made and turns out badly, several difficult issues arise. Should the video be erased or deleted? If the recording is retained, will it aid the will contestant if shown? What response is proper if during the deposition stage of a will contest the attorney is asked whether the will execution ceremony was video-recorded? What can the attorney do to prevent the potentially damaging recording's introduction short of perjury? There are few, if any, good answers to these questions.

\section{Staged}

Opposition to the use of a video of the will execution ceremony may stem from the staged nature of the recording which arguably reduces its probative value. This objection is not unique to video-recorded evidence.

65 In such cases, an audio-only tape may be appropriate. See Joseph S. Horrigan, Will Contest: Evidence, Procedure, and Experts, in STATE BAR of Texas, 15TH AnNual Advanced Estate PlanNing AND PRobate CoURSE M-2 (1991).
Commonly, the testimony of live witnesses is rehearsed many times before it is given under oath. A witness in court is subject to crossexamination, however, while it is impossible to question a video and its principal, the testator. This objection should be easily surmounted because, unlike a reenactment or demonstration, the will execution ceremony is a staged event in the first place.

\section{Distortion}

Video-recordings have the potential to distort the people and events recorded. Viewed on video, the testator may appear different than the testator would in person; the testator may appear heavier, or scars and blemishes may be accented. Although distortions are inadvertent and inherent in any recording process, some distortion could be intentionally done to bolster the testator. For example, the attorney could instruct the camera operator to avoid recording the testator's perceived negative traits which would adversely impact a determination of testamentary capacity.

\section{Alteration}

There is always a possibility that the video-recording of the will execution ceremony will be altered. The alteration could be accidental through inadvertent erasure, deletion, or exposure to a strong magnetic field. Careful storage procedures, however, greatly reduce these risks.

Intentional alteration through skillful editing and dubbing may also occur, although a video is more difficult to alter than a written document. Even though anyone with correction tape or fluid, scissors, a photocopier, and a bit of evil ingenuity can alter a written document, more sophisticated equipment and skills are required to make undetectable changes to a video. Use of a continuous display time-date generator along with a storage method requiring a documented chain of custody significantly reduces the possibility of tampering. 


\section{E. Procedure/Format for Videotaping Will Execution Ceremony}

Once the decision is made to video-record the will execution ceremony, caution must be exercised to make certain the recording contains all the necessary elements and does not contain anything detracting from admissibility or evidentiary weight.

\section{Inspect Equipment}

The recording equipment should be inspected to insure it is in proper working order and a competent operator should be available at the appointed time.

\section{Fully Brief Prospective Testator}

The prospective testator should be fully briefed as to how the recording procedure will be conducted. In some situations, a "dress rehearsal" may be necessary to familiarize the testator with the recording process and avoid an appearance of anxiety or nervousness. It is important that the testator is comfortable and at ease with the situation so that the testator appears and sounds natural. Likewise, it must be impressed on the testator that all actions and statements will be recorded. Avoidance of emotional outbursts and unplanned conversation is crucial. The testator should also be instructed to avoid any potentially annoying habits such as fingernail biting and smoking.

\section{Prepare Room}

The room in which the recording takes place needs to be carefully prepared. Desks, tables, chairs, and so forth should appear neat and uncluttered so nothing detracts from the participants' words and actions. The room should be arranged so that a camera operating from a fixed location can record all relevant events.

\section{Gather Participants}

Once the room is ready, the appropriate persons should be gathered. In most cases, the only individuals present will be the testator, the attorney, two or three witnesses, a notary, and the equipment operator. To reduce claims of overreaching and undue influence, beneficiaries and family members should be excluded. In addition, no one should enter or leave the room until recording is complete.

\section{Position Participants}

All participants in the ceremony need to be strategically positioned in the room so that they may be easily recorded performing their various duties. For example, the testator and witnesses should be seated so they, as well as the camera, can observe the execution and attestation of the will.

\section{Introductions by Attorney (pre-recording)}

Before the recording begins, the attorney should thank everyone for coming and briefly review what is going to happen. The attorney should answer any last minute questions and resolve concerns. Only after everything and everyone is ready should the actual recording begin.

\section{Begin Recording; Introduce Setting and $\underline{\text { Participants }}$}

As an introduction, the attorney in charge of the ceremony should identify the situation (a will execution ceremony), state the location of the recording, and give the date and time. The camera should have a time-date generator which continuously records the date and time on the recording. The camera should then pan the entire room and each person should state his or her name, address, and role in the ceremony (e.g., witness, notary).

\section{Identify Testator and Establish Awareness of Recording}

The camera should then focus on a dialogue between the testator and the attorney. The testator should state the testator's name and explain that the testator is preparing to execute a will to control the disposition of the testator's property upon death. Likewise, the testator should indicate an awareness that the 
ceremony is being recorded with the testator's full knowledge and consent.

A brief period of recorded "small talk" may also be helpful to establish the testator's competency. The conversation should be crafted to include some references to things in the past to establish long-term memory (e.g., when did you get married, where did you go to high school) and to recent events to demonstrate short-term memory (e.g., what did you eat for breakfast, what did you do last night).

\section{Demonstrate Testator's Agreement to Will Terms}

The testator should then identify the appropriate document as the testator's will. The testator should read the entire will aloud, and the camera should zoom in on the will so that each page will be readable during playback. This part of the procedure is very important because it helps ensure that the document probated is identical to the one actually executed. If the testator objects to revealing the contents of the will to the witnesses and other personnel, they may leave the room during the reading of the will. The testator should then state that the testator understands the will and agrees with its dispositive and administrative provisions.

\section{Establish Testator Understands Natural Objects of Bounty}

The video-recording should establish that the testator understands the natural objects of the testator's bounty. The testator should provide details concerning prior marriage(s), if any (e.g., ex-spouses' names, how the marriages ended, such as by death or divorce). If the testator has any children, the testator should give their names, ages, and addresses along with information regarding other close family members such as parents, siblings, and grandchildren. This part of the ceremony is especially important if a spouse or child is being disinherited in favor of a distant relative, friend, or charity.

\section{Establish Testator Understands Nature and Extent of Property}

The recording should also demonstrate that the testator understands the nature and extent of the testator's property. To accomplish this, the testator should explain the types and approximate value of the testator's assets. In addition, the testator should state when the property was acquired and the source of payment to help establish the community or separate character of the property. This will help avoid claims that the testator made a will believing the contents or value of the testator's estate to be vastly different from its true condition.

\section{Establish Testator Understands \\ Disposition of Property Made by Will}

The recording should reflect the testator's understanding of the disposition of the testator's property. If the testator makes controversial or unusual gifts or if close family members are omitted, it may be advisable for the testator to explain the testator's disposition plan and the reasons therefore. 66

\section{Establish Lack of Undue Influence}

The video-recording might also be used to rebut claims that the testator was exposed to undue influence. In this regard, the attorney should ask the testator if others have badgered the testator to make a will containing particular provisions. If any of those persons are present, they should be asked to leave. The attorney should also ask the testator whether anyone has threatened to withhold medicine, food, or love or threatened to harm the testator in any way if the will was not written in a certain manner. The attorney should pose sufficient questions to convince someone watching the tape that the will reflects the testator's disposition plan and not that of someone else.

\footnotetext{
${ }^{66}$ See supra § III, page 5.
} 


\section{Permit Testator to Discuss Will Contest} Suspicions

If the testator has any particular fears or suspicions that unhappy heirs are likely to contest the will, the testator should explain the grounds for these concerns. The recording's usefulness to prevent or win a will contest action is increased if the testator discusses the exact grounds for contest and provides appropriate explanations. Prior to the ceremony, the attorney must caution the testator to refrain from using language that might provoke a will contest or be considered slanderous.

\section{Conduct Standard Will Execution Ceremony}

The next part of the video-recording procedure is the standard will execution ceremony as discussed in $\S$ VI. The attorney should ask the testator if the testator requests the witnesses to attest to the signing of the will. The testator should clearly answer in the affirmative. The testator should then initial each page of the will and sign it at the end while the camera focuses on the testator's actions and the witnesses observing the testator signing the will. Next, the attorney or a witness should read the attestation clause. All witnesses should then initial each page of the will and sign at the end. The camera should follow the action closely so that the tape records the actual attestation and the testator's observation thereof.

\section{Execute Self-Proving Affidavit}

For the details of the procedure for executing the self-proving affidavit, see $\S \operatorname{VI}(\mathrm{B}) 12$.

The actual ceremony would then be finished and recording would stop.

\section{Review Recording}

The recording should be viewed to ensure that all appropriate words and actions were clearly recorded. This step also helps establish that the equipment was functioning properly, the operator was competent, and the recording accurately reflects what transpired.

\section{Obtain Affidavit of Equipment Operator}

The camera operator should sign an affidavit describing the operator's experience and qualifications, explaining the type of equipment used, and stating that the equipment was in proper working order during the recording. This would be helpful if a foundation for admissibility is needed and the camera operator or other witnesses are unavailable.

\section{Store Video-recording in Secure Location}

The video should be stored so it is safe from fire, theft, magnetic fields, heat, and unauthorized access. This storage location should be readily accessible upon the death of the testator. A common repository is a safe deposit box because its entry records are useful in showing the recording's chain of custody.

\section{F. Conclusion}

The legal profession, steeped in tradition and precedent, is often hesitant to adopt new techniques. To provide clients with the best legal services available, however, estate planners must remain abreast of technological developments such as video-recording. Each time a will is prepared, the drafter should determine the likelihood of whether additional evidence of the will execution ceremony will be necessary. If so, serious consideration should be given to video-recording the will execution ceremony. This modern procedure permits the accurate preservation of the testator's words and actions. The superior evidence of the testator's mental and physical condition provided by a video may prove invaluable should a will contest materialize. Although not without its disadvantages, the use of video has a tremendous potential for avoiding a successful will contest and improving the likelihood that testamentary desires are effectuated. 


\section{SELECT WITNESSES THOUGHTFULLY}

Little thought is usually given to the selection of witnesses. Typically, witnesses are individuals who just happen to be available at the time of will execution, e.g., secretaries, paralegals, law clerks, and other attorneys. It may be that the testator sees the witnesses for the first and last time at the ceremony. In most cases, this practice is not harmful; the self-proving affidavit removes the necessity for finding the witnesses and the vast majority of wills are uncontested. The situation is considerably different, however, if a contest arises and the testimony of the witnesses as to testamentary capacity or the details of the will execution ceremony is crucial.

\section{A. Witnesses Familiar with Testator}

"The jury is likely to give little weight to the testimony of a witness who never saw the testator before or after the execution of the will, and whose opportunity to form a conclusion was limited to the single brief occasion."67 Accordingly, if the attorney anticipates a will contest, it is prudent to select witnesses previously acquainted with the testator, such as personal friends, coworkers, and business associates. These people are more likely to remember the ceremony and provide testimony about how the testator acted at the relevant time. In addition, they can compare the testator's conduct at the ceremony with how the testator acted at a time when the contestants concede that the testator had capacity.

Considerable debate exists regarding the wisdom of having health care providers serve as witnesses or attend the will execution ceremony. The doctors and nurses who care for the testator appear well-qualified to testify about the testator's condition. During crossexamination, however, details about the

6717 Marion K. WOODWARD \& ERNEST E. Smith, III, Probate and Decedents' Estates $\S 336$, at 278 (Texas Practice 1971). testator's illness may come out that would not otherwise have been discovered. This additional information may prove sufficient to sway the fact-finder to conclude the testator lacked capacity. ${ }^{68}$ The danger is heightened if the doctor is a psychiatrist. "The very presence of a psychiatrist may be seized upon by the contestant as indicative of doubt as to testamentary capacity and, by adroit handling, may be caused to operate adversely to the proponent." 69

\section{B. Supernumerary Witnesses}

Although attested wills require only two witnesses under Texas law, ${ }^{70}$ extra witnesses may be advisable if a contest is likely. Additional witnesses provide a greater pool of individuals who may be alive, available, and able to recollect the ceremony and the testator's condition.

\section{Youthful and Healthy Witnesses}

The attorney should select witnesses who are younger than the testator and in good health. Although it is no guaranty, the use of young, healthy witnesses increases the likelihood that they will be available (alive and competent) to testify if the will is contested.

\section{Traceable Witnesses}

An attorney charged with locating attesting witnesses to counter a will contest is often faced with a difficult task. Witnesses may move out of the city, state, or country. In addition, witnesses may change their names (e.g., a female witness marries and adopts husband's name or a married female divorces and retakes maiden name). To increase the chance of locating crucial witnesses, the attorney should select people who appear easy to trace, e.g., individuals with close family,

68 See Charles C. Allen, The Will Contest: An Acid Test of Will Drafting, 6 ST. LouIS U.L.J. 1, 18 (1960).

69 Jaworski, supra note 41, at 93.

70 TeX. Prob. Code $§ 59$. 
friendship, business, educational, or political ties with the local community.

\section{E. Witnesses Who Would Favorably Impress the Court and Jury}

The attorney should carefully evaluate the personal characteristics of the witnesses. The witnesses should be people who would "make a good impression on the court and jury substantial people of strong personality who speak convincingly and with definiteness."71

\section{OBTAIN AFFIDAVITS OF INDIVIDUALS FAMILIAR WITH TESTATOR}

One of the most convincing types of evidence of a testator's capacity is testimony from individuals who observed the testator at and around the time the will was executed. Frequently, however, this testimony is unavailable at the time of the will contest action; the witnesses to the will may be dead, difficult to locate, or lack a good recollection of the testator. The same may be true of other individuals who had personal, business, or professional contacts with the testator. One way of preserving this valuable evidence is to obtain affidavits from these people detailing the testator's conduct, physical and mental condition, and related matters. Affidavits of attesting witnesses, individuals who spoke with the testator on a regular basis, or health care providers (doctors, psychiatrists, nurses) who examined the testator close to the time of will execution, will help protect this potentially valuable testimony should a will contest arise.

\section{DOCUMENT TRANSACTIONS WITH TESTATOR VERIFYING INTENT}

Under normal circumstances, the testator orally explains the desired disposition plan

\footnotetext{
71 Jaworski, supra note 41, at 91 .
}

and the reasons therefore, the attorney takes scribbled notes, the attorney prepares a draft of the will, the testator makes oral corrections, and then the attorney prepares the final version of the will. This procedure supplies little in the way of documentation to refresh the attorney's memory about the details of the testator's situation nor to use as evidence in a will contest action. If a contest is anticipated, all of these steps should be documented in writing, on videotape, or both. For example, the testator could write a letter to the attorney explaining the disposition scheme and motivating factors behind it. The attorney's written reply would warn that a contest may occur because of the disinheritance of prospective heirs, unequal treatment of children, excessive restrictions on gifts, etc. The testator would respond in writing that the testator has considered these factors but prefers to have property pass as originally indicated. The attorney should take detailed notes of all meetings with the testator as well as of the will execution ceremony. The attorney would then carefully preserve these documents for use should the will be contested. ${ }^{72}$

\section{OBTAIN OTHER EVIDENCE TO DOCUMENT TESTATOR'S ACTIONS}

Gathering evidence to rebut a will contest is always easier while the testator is alive. Along with affidavits of individuals familiar with the testator and documenting testator's intent, the attorney may want to acquire additional evidence. For example, the testator may have letters from a child showing family discord supporting the testator's reasons for disinheriting the child. Or, the attorney may wish to collect the testator's medical records and may easily do so by having the testator sign a release.

\footnotetext{
72 See Jaworski, supra note 41, at 91-93.
} 


\section{PRESERVE PRIOR WILL}

When a new will is executed, it is common practice to physically destroy prior wills. If the testator's capacity is in doubt, however, and the testator indicates that the testator prefers the prior will to intestacy, it is a good idea to retain the prior will. If a court holds that the new will is invalid, the attorney may offer the old will for probate much to the chagrin of the contestant. ${ }^{73}$

\section{REEXECUTE SAME WILL ON REGULAR BASIS}

What happens when a will contest is successful? The estate passes under a prior will, or if none, via intestacy. As discussed in $\S$ XII, it may be a good idea to preserve a prior will if the testator prefers its disposition to intestacy. However, the testator clearly prefers the new will to both the old will and intestacy. Thus, the attorney could have the testator reexecute the same will on a regular basis, for example, once every six months. At the time of the testator's death, the most recent will would be offered for probate. If a contest is successful, then the will executed six months prior would be introduced. If that one is likewise set aside, the will executed one year prior would be introduced, and so on until all wills are exhausted. A potential contestant might forego a contest when the contestant realizes that sufficient reasons for contest would have to be proved for many different points in time. ${ }^{74}$

73 See Jaworski, supra note 41, at 95.

74 See Brown, Re-Signed Will-Revisited, $36 \mathrm{~J}$. St. B. CAL. 344 (1961); Brown, The Re-Signed Will, 35 J. ST. B. CAL. 685 (1960).
XIV. SUGGEST THAT TESTATOR CONSIDER MAKING A MORE TRADITIONAL DISPOSITION

Unusual dispositions, such as those disinheriting close family members, treating like-situated children differently, and imposing excessive restrictions on gifts, are apt to trigger contests. Therefore, the attorney may wish to suggest that the testator consider toning down the disposition plan to bring it closer to conforming to a traditional arrangement. Of course, the client may balk at this recommendation. The attorney should explain that although this may cause the testator to deal with property in an undesired way, it may reduce the motives for a contest and thus increase the chances of the will being uncontested. (Or stated another way, half a loaf is better than no loaf at all.) Alternatively, other estate planning techniques may be used to make unconventional dispositions.

\section{MAKE SIGNIFICANT INTER VIVOS GIFT TO DISINHERITED HEIR APPARENT AT TIME OF WILL EXECUTION}

The testator may wish to make an inter vivos gift, either outright or in trust, to a disinherited heir apparent at the same time the will is executed (i.e., minutes after will execution). This gift should be substantial but, of course, far less than the amount the heir apparent would take via intestacy. After the testator's death, the heir is less likely to contest the will on the basis of lack of testamentary capacity. By asserting lack of capacity, the contestant would be forced to concede that the contestant accepted property from a person who lacked the capacity to make a gift or establish a trust. In addition, should the contest succeed, the heir would be required to return any property already 
received to the estate or use it to offset the intestate share.

\section{CONTRACT NOT TO CONTEST}

The testator could enter into a contract not to contest with the potential will contestants. ${ }^{75}$ In exchange for the payment of money or a transfer of other property, the heirs (or beneficiaries of prior wills) could bind themselves contractually not to contest the will. If the contract is drafted to meet all the elements of a valid contract, it should be enforceable, especially in light of the cases validating a contract to convey an inheritance. ${ }^{76}$

\section{RECOMMEND USE OF ALTERNATIVE ESTATE PLANNING TECHNIQUES}

Whenever the attorney anticipates a will contest, the attorney should consider using other estate planning techniques to supplement the will. Inter vivos gifts, either outright or in trust, multiple-party accounts, and life insurance, annuities, and other death benefit plans are just some of the alternative techniques available to the estate planner. Although these arrangements may be set aside on grounds similar to those for contesting a will, such as lack of capacity or undue influence, they may be more difficult for a contestant to undo. More people may be involved with the creation or administration of these techniques thereby providing a greater number of individuals competent to testify about the client's mental condition. In addition, the contestant may be estopped from contesting certain arrangements if the

75 See Letter from Robert Jorrie, attorney, San Antonio, Texas, to Michael Cenatiempo, attorney, Houston, Texas (Feb. 22, 1994).

76 See Mow v. Baker, 24 S.W.2d 1 (Tex. Comm'n App. 1930, holding approved). contestant has already accepted benefits as, for example, a beneficiary of a trust. Furthermore, many of these techniques may be used to secure other benefits such as tax reduction, reduced need for guardianship, probate avoidance, and increased flexibility.

\section{ANTE-MORTEM PROBATE}

$$
\begin{gathered}
\text { "[T] he post mortem squabblings and } \\
\text { contests on mental condition . . have } \\
\text { made a will the least secure of all } \\
\text { human dealings." } 77
\end{gathered}
$$

The ultimate goal of estate planning is to ascertain and effectuate the intent of each individual to the fullest extent possible within legal boundaries. One of the most common estate planning techniques used to accomplish this laudable purpose is the will, a document memorializing a person's desires regarding the disposition of property, designation of fiduciaries, and other related matters, which is poised to take effect upon the testator's death.

Formal proof of a person's will may not occur in Texas until after the testator's death. This procedure prevents the person who has the most important evidence of intent, the testator, from testifying. Consequently, estate planners are constantly striving to ascertain whether all technical requirements for a valid will are satisfied as well as preparing for potential battles against disgruntled heirs preferring an ineffective will so that they may receive a larger portion of the decedent's estate via intestate distribution or an earlier will. A progressive technique with tremendous potential for improving the estate planner's ability to assure that a testator's desires will be carried out upon death is to validate the will during the testator's lifetime - an ante-mortem or living probate. The testator would then be assured that the testator's wishes will be carried out after

77 Lloyd v. Wayne Circuit Judge, 23 N.W. 28, 30 (Mich. 1885). 
death and will be able to die with the knowledge and confidence that the will is safe from contest. 78

\section{A. Significant Problems With Post- Mortem Probate Under Texas Law}

Although functioning adequately in the majority of situations, post-mortem probate poses many difficulties which frustrate the intent of the testator as well as waste court time and estate resources. A few of these problems will be discussed along with some of the traditional solutions used to ameliorate these problems.

\section{Mere Technical Errors May Invalidate Otherwise Valid Will}

Under Texas law, even the simplest of errors can result in the invalidation of the testator's entire will despite clear and convincing evidence that the testator was competent and truly intended the disposition plan directed in the will. For example, the testator may not be in the presence of the witnesses when they attest to the will. ${ }^{79}$ Other situations leading to invalidity include the will having only one witness, an unwitnessed will containing too much material not in the testator's own handwriting to qualify as a holographic will, and the incompetency of one of the witnesses.

To avoid these problems, a person may elect to use various non-probate transfers such as inter vivos trusts, joint ownership with survivorship rights, and outright gifts. Despite the effectiveness of these techniques in many circumstances, they have potentially

78 See Aloysius A. Leopold \& Gerry W. Beyer, Ante-Mortem Probate: A Viable Alternative, 43 ARK. L. REV. 131 (1990) (portions of this section are adapted from this article).

79 Morris v. Estate of West, 643 S.W.2d 204, 206 (Tex. App.-Eastland 1982, writ ref'd n.r.e.) (court invalidated a will because the testator could not have observed the witnesses signing the will without walking four feet to an office door and fourteen feet down a hallway). undesirable consequences, e.g., outright gifts require total control over the property to be sacrificed, trusts may be set aside for lack of capacity or undue influence, and joint ownership may give too many rights to the joint owner. Public policy is not served when the use of non-probate transfers is primarily motivated by fears that testamentary instructions will not be carried out.

\section{Spurious Will Contests Encouraged}

One of the laudable purposes of a will contest is to ensure that deserving heirs are not deprived of a share of the decedent's estate as a result of the testator's lack of capacity when the will was executed or because a devious person defrauded or exerted undue influence on a susceptible testator. Synthesized by greedy plots of unhappy heirs, however, will contests are often filed to prove lack of mental capacity, fraud, or undue influence where none existed. Even if the contest is unsuccessful, estate funds are wasted and innocent beneficiaries must endure emotional upheaval and delay. Unfounded will contests may also lead to settlements entered into only to prevent further depletion of the estate and which result in distributions not intended by the testator.

\section{Testator Unavailable to Testify}

An inherent difficulty with post-mortem probate is that it requires the trier of fact to determine the competency and desires of the testator without having the key witness, the testator, available for questioning. Only indirect evidence is available to evaluate the testator's capacity which, whether the testator was incompetent or simply eccentric with property, tends to be a matter of mere speculation. The quality of any evidence, such as the testimony of witnesses to the will, tends to deteriorate with time as memories fade and perceptions change.

A relatively modern technique which may be used to partially solve this problem is to 
videotape the will execution ceremony. ${ }^{80}$ If the will execution ceremony is preserved on videotape, the testator is effectively brought into the courtroom during a contest although, of course, the testator is not subject to cross examination. Despite the tremendous benefits of this technique, it pales in comparison to ante-mortem probate where the actual testator is available for direct observation.

\section{B. Development of Ante-Mortem Probate}

Although it may seem like a modern device, ante-mortem probate is not a new idea. Underpinnings of ante-mortem concepts may be found in the Bible as well as in both English common law and European civil law. The first serious attempt at ante-mortem probate in the United States occurred in Michigan near the end of the nineteenth century.

\section{The Michigan Attempt at Ante-Mortem Probate}

In 1883, the Michigan Legislature enacted what appears to be the first ante-mortem statute in the United States. ${ }^{81}$ This statute authorized the testator to petition the probate judge of the testator's county of residence for a decree establishing the will as the testator's last will and testament and for admittance to probate. Notice of the ante-mortem procedure would be sent to the testator's heirs after which the probate judge would conduct a hearing, similar to that for a traditional probate. If the judge determined the testator was of sound mind and executed the will without fear, fraud, impartiality, or undue influence and with a full knowledge of its contents, the judge would issue an antemortem decree which would be attached to the will. This decree would have the same effect as a post-mortem decree validating the will and would be conclusive as to the matters stated therein.

\footnotetext{
80 See supra $\S$ VII, page 13.

811883 Mich. Pub. Stat. 17.
}

Unfortunately, the usefulness of this innovative statute was short-lived. In 1885, the Michigan Supreme Court declared the ante-mortem statute unconstitutional for its failure to provide proper notice to the parties, failure to provide for finality of judgment, and because the court believed ante-mortem procedures were beyond the judicial power traditionally exercised by courts at common law. ${ }^{82}$ The court viewed ante-mortem probate as a type of declaratory judgment which, under the law at that time, was not allowed.

\section{The Texas Attempt at Ante-Mortem Probate}

In 1943, the Texas Legislature enacted a comprehensive statute authorizing courts to make declaratory judgments. One of the statute's provisions allowed an interested person under a will to have any question of construction or validity arising thereunder determined by a declaratory judgment. ${ }^{83}$ The door to ante-mortem probate was thus opened, and it was less than ten years later that living probate was tested under this statute.

In Cowan v. Cowan, ${ }^{84}$ two of the testator's three children sought to have the will of their living mother declared invalid on grounds of lack of testamentary capacity, insane delusions concerning the objects of her bounty, and undue influence. Despite the seeming authorization of such actions by the declaratory judgment statute, the court determined that it had no jurisdiction to determine the validity of a will of a person who was still alive. The court reasoned that because it did not have such jurisdiction prior to the enactment of the declaratory judgment statute, it did not subsequently obtain that jurisdiction; the declaratory judgment statute did not create new substantive rights but was

${ }^{82}$ Lloyd v. Wayne Circuit Judge, 23 N.W. 28, 29 (Mich. 1885).

83 Tex. Civ. Prac. \& Rem. Code $\$ 37.004$ (original version substantially similar).

84254 S.W.2d 862, 863 (Tex. Civ. App.Amarillo 1952, no writ). 
only remedial in nature and provided a new method of exercising existing jurisdiction. The court noted that the will was ambulatory and that "those named as beneficiaries are devisees only in the embryo." Additionally, the Probate Code did not permit the probate of a will of a living person. ${ }^{85}$

No reported case has been located subsequent to Cowan where a Texas court discussed ante-mortem probate. Thus, it would appear that express enabling legislation will be required to bring ante-mortem probate within the purview of the Texas declaratory judgment statute.

\section{Current Status of Ante-Mortem Probate}

\section{Models of Ante-Mortem Probate}

During the 1970s and 1980s, legal commentators developed three basic models of ante-mortem probate and have intensely debated the value of each of these methodologies as well as the viability of antemortem probate in general.

\section{a. Contest Model}

The original model for ante-mortem probate has been called the contest model. The testator would execute the will and then ask for a declaratory judgment ruling the will valid, i.e., that all technical formalities were satisfied, the testator had the required testamentary capacity to execute a will, and was not under undue influence. The beneficiaries of the will and the heirs apparent (those who would receive property from the testator's estate were the testator now to die intestate) would be given notice so they would be able to contest the probate of the will. If the court found that the will was valid, it would be effective to dispose of testator's property unless the testator made a new will

85 Tex. Prob. Code $\S 72$ (prior version substantially similar). or otherwise revoked the one proven via this procedure. 86

\section{b. Conservatorship Model}

Like the contest model, the conservatorship model is built on a declaratory judgment base. The testator would petition the court for a declaration of the will's validity, and notice would be given to all the beneficiaries and heirs apparent. In addition, a guardian ad litem would be appointed to represent these interested parties as well as unborn and unascertained beneficiaries and heirs. Thus, there would be no need for an heir apparent or beneficiary to contest the ante-mortem probate; the guardian ad litem would represent these individuals. In ascertaining whether the testator had the required mental capacity to make a will, the judge would evaluate the results of a medical examination of the testator and other relevant evidence prior to rendering a decision. ${ }^{87}$

\section{c. Administrative Model}

Departing from both the contest and conservatorship models, the administrative model is based on an ex parte proceeding rather than an adversarial action. The antemortem probate would begin in the same manner, that is, the testator would petition the court for a declaration that the will complies with all necessary formalities, that the testator had the requisite capacity, and there was no undue influence. The court would then appoint a guardian ad litem. Unlike proceedings under the conservatorship model, however, the guardian would act for the court to determine facts, rather than represent the individual interests of the heirs apparent or beneficiaries. The guardian would interview the testator and others to ascertain the testator's capacity and freedom from undue

86 See Howard Fink, Ante-Mortem Probate Revisited: Can An Idea Have a Life After Death?, 37 OнIо ST. L.J. 264 (1976).

87 See John H. Langbein, Living Probate: The Conservatorship Model, 77 Mich. L. REV. 63 (1978) 
influence. Because of this arrangement, notice to the heirs apparent or to others would not be required; the court would examine the evidence brought forth by the guardian ad litem in deciding whether the will is entitled to ante-mortem probate. ${ }^{88}$

2. Jurisdictions Which Currently Have AnteMortem Probate

In the waning years of the $1970 \mathrm{~s}$, three states enacted ante-mortem statutes based on the contest model: Arkansas, ${ }^{89}$ North Dakota, ${ }^{90}$ and Ohio. ${ }^{91}$ Despite its status as the oldest ante-mortem statute, the North Dakota Ante-Mortem Probate Act is rarely used. When the procedure is used, however, the proceedings appear to progress smoothly. The Ohio ante-mortem statutes have generated the greatest use, perhaps because of Ohio's large population and thus the increased chance of interest in ante-mortem probate. Several appellate cases have addressed various aspects of the statute and one court held the procedure constitutional. ${ }^{92}$ The most frequent use of the procedure has been where an attorney has prepared a will for an elderly person or a person under guardianship. ${ }^{93}$ The Arkansas provisions appear to be virtually ignored by attorneys and lay persons alike.

"In 2010, Alaska reignited the interest in ante-mortem probate when it enacted the first ante-mortem probate legislation since the Arkansas statute. ${ }^{94}$ With the interest in ante-

88 See Gregory S. Alexander \& Albert M. Pearson, Alternative Models of Ante-Mortem Probate and Procedural Due Process Limitations on Succession, 78 Mich. L. REV. 89 (1979).

${ }^{89}$ ARK. STAT. $\S \S 28-40-201$ to -203 (2004).

90 N.D. CENT. CODE $\S \S 30.1-08.1-01$ to -04 (1996).

91 OHIO REV. CODE $§ \S 2107.081-.085$ (2005).

92 Cooper v. Woodard, 1983 WL 6566 (Ohio Ct. App.).

93 See Horst v. First Nat'l Bank in Massillon, 1990 WL 94654 (Ohio App.).

94 Alaska StAT. $§ 13.12 .530-.590$. mortem probate gaining momentum, Nevada soon followed in enacting its own antemortem probate legislation. ${ }^{95}$ As with the previous states to enact ante-mortem probate, both Alaska and Nevada enacted a form of the Contest Model. Unlike the previous statutes, both Alaska and Nevada also provided for the validation of a trust during a settlor's lifetime."96

\section{Uniform Laws}

The National Conference of Commissioners on Uniform State Laws gave serious consideration to ante-mortem probate in the early 1980s. Two proposals were carefully examined: one based on the contest approach and another based on the administrative model. Despite several meetings and detailed discussions, the Joint Editorial Board-Uniform Probate Code Committee was divided on whether to continue the ante-mortem project. Due in part to this split, the Drafting Committee voted to cancel the project thus deflating the hopes of a quick response to the need for uniform legislation. Renewed interest in preparing a uniform ante-mortem act has yet to occur.

\section{The Future of Ante-Mortem Probate}

Ante-mortem probate has the potential of greatly improving the legal system's effective transmittal of an individual's wealth by providing the testator with greater certainty that the testator's desires for the distribution of property will be fulfilled and designation of fiduciaries followed according to the testator's written declaration. Because the validity of the will would be determined prior to the testator's death when all relevant evidence is before the court, will contests would be greatly reduced. In addition, ante-mortem probate would lead to more efficient use of scarce and valuable resources as less court

\footnotetext{
95 NeV. Stat. Ch. 263.

96 Joseph Savoie, The Commissioners' Model of Ante-Mortem Probate, _ ACTEC J. (201_).
} 
time is expended dealing with spurious will contests and fewer estate funds are dissipated defending those contests.

Admittedly, ante-mortem probate is not a panacea. The ante-mortem process, especially one based on the contest model, may be extremely disruptive to the testator and the testator's family. The testator may not wish to disclose the contents of the will nor to face the potential embarrassment that may occur if testamentary capacity is litigated. Additionally, the process involves additional costs and may raise due process and conflict of laws problems. The benefits of antemortem probate, however, should not be withheld from the public merely because the technique is not flawless or because it may be difficult to determine the proper model to use.

In 1994, the Texas Real Estate, Probate \& Trust Law Council studied the possibility of drafting a Texas ante-mortem statute. Despite believing that ante-mortem probate would be a useful procedure, the Council decided not to move forward with legislation because of the existence of more pressing concerns.

\section{TORTIOUS \\ INTERFERENCE WITH INHERITANCE RIGHTS}

Texas law recognizes the tort of interference with inheritance rights. ${ }^{97}$ It appears that this tort action may be brought while the person is still alive, even though the property is merely an expectancy interest which does not vest until death. ${ }^{98}$ The analysis of one commentator is especially useful.

97 See King v. Acker, 725 S.W.2d 750 (Tex. App.-Houston [1st Dist.] 1987, no writ); Neill v. Yett, 746 S.W.2d 32 (Tex. App.-Austin 1988, writ denied).

98 See Carlton v. Carlton, 575 So. 2d 239 (Fla. Dist. Ct. App. 1991); Harmon v. Harmon, 404 A.2d 1020 (Me. 1979).
Thus, a plaintiff may maintain a cause of action during a testator's lifetime for interference with an intended legacy, for instance, due to revocation or execution of a will as a result of undue influence or fraud. In this situation, the tort action is something of a "living" will contest in that it may resolve conclusively many of the issues that ordinarily would be considered only after a decedent's death ... preventing relitigation of those issues after death. 99

Many of the advantages of ante-mortem probate are also available with an intentional interference action. For example, the testator is available for questioning and the memories of witnesses are more current.

Texas courts have not delineated exactly what actions constitute tortuous interference with inheritance rights. Taking an opposite approach, the 2003 Legislature declared that certain specified actions may not be considered tortuous interference, that is, the filing or contesting in probate court of any pleading relating to a decedent's estate. 100
99 M. Read Moore, At the Frontier of Probate Litigation: Intentional Interference With the Right to Inherit, ProB. \& Prop., Nov./Dec. 1993, at 6, 7.

100 Tex. Prob. CodE $\S 10 \mathrm{C}$. 